\title{
Fotografía y memoria en la dictadura argentina (1976-1983). Entrevista con Eduardo Longoni
}

\section{Photography and Memory in the Argentinean Dictatorship (1976-1983). Interview with Eduardo Longoni}

\author{
Alberto del Castillo Troncoso \\ Instituto de Investigaciones Dr. José María Luis Mora | adelcastillo@institutomora.edu.mx
}

\begin{abstract}
Resumen
En este artículo se reflexiona sobre el papel de la fotografía en la construcción de la memoria en torno a la dictadura militar argentina. Para ello se presenta y analiza una entrevista original con Eduardo Longoni, uno de los fotógrafos más destacados de la historia reciente, creador de algunos de los iconos más emblemáticos de la dictadura.
\end{abstract}

Palabras clave: fotografía; represión; violencia; derechos humanos; dictadura.

\section{Abstract}

This article reflects on the role of photography in the construction of memory regarding Argentina's military dictatorship. It therefore presents and analyzes an original interview with Eduardo Longoni, one of the leading photographers in recent history and the creator of some of the most emblematic icons of the dictatorship.

Key words: photograph; repression; violence; human rights; dictatorship.

Fecha de recepción: 8 de octubre de 2014 Fecha de aceptación: 14 de enero de 2015 


\title{
Fotografía y memoria en la dictadura argentina (1976-1983). Entrevista con Eduardo Longoni
}

\author{
Alberto del Castillo Troncoso
}

\section{LA CONSTRUCCIÓN DE LA MEMORIA Y LAS DISTINTAS REPRESENTACIONES DE LA DICTADURA*}

\section{L} a dictadura militar que se instauró en Argentina entre los años 1976 y 1983 constituye un régimen que ha sido calificado por los historiadores bajo la categoría de "terrorismo de Estado", ya que se distingue de los gobiernos castrenses anteriores en el hecho de que en esta ocasión la represión contra la disidencia política implicó la participación del Estado en la construcción y adaptación de cientos de campos de detención, cautiverio y exterminio a lo largo del territorio argentino y en el que al margen del Estado de derecho fueron secuestradas, torturadas y sacrificadas miles de personas de manera clandestina. Al mismo tiempo, varios centenares de personas huyeron del país y se exiliaron en distintas partes del mundo.

La política castrense instrumentó férreas condiciones de censura y autocensura para todos los medios y arrojó un saldo de un poco más de 100 periodistas asesinados durante los primeros años del régimen. El ejercicio de la memoria en torno a esos años de plomo ha pasado por varias etapas y no ha seguido una evolución lineal o acumulativa, sino que ha implicado una serie de avances y retrocesos, de acuerdo con cada coyuntura (Lvovich y Bisquert, 2008).

* Este artículo constituye uno de los resultados de la estancia sabática que realicé con el apoyo del Instituto Mora y el ConACYT en el Instituto Gino Germani de la ciudad de Buenos Aires entre febrero de 2104 y enero de 2015, bajo la coordinación de la doctora Ana Longoni. Agradezco a Cora Gamarnik y Julio Menajovsky por sus comentarios y sugerencias y, por supuesto, a Eduardo Longoni por toda su generosidad y buena disposición para conversar conmigo durante cerca de quince horas en distintas entrevistas realizadas en su departamento en el barrio de Belgrano, entre los meses de septiembre y diciembre de 2014. 
En lo que respecta al tema de la represión política y los derechos humanos, la sociedad argentina ha transitado de la negación, la incredulidad y la desconfianza propia de los últimos años de la dictadura a la generación de expectativas de cambio a mediados de los años ochenta del siglo pasado, pasando por la impunidad y el aparente olvido de estos temas en los noventa, hasta la renovación de un ejercicio de la memoria colectiva a partir del 20 aniversario del golpe y, posteriormente, la creación de una política de Estado en torno al tema en los inicios del nuevo siglo. ${ }^{1}$

En todos estos años la tensión entre los distintos sectores no está caracterizada por la dicotomía entre memoria y olvido, sino por la confrontación de distintos proyectos de memoria (Jelin, 2012). En todo este proceso, la fotografía ha desempeñado un papel muy relevante.

Por todo lo anterior, es importante regresar a los años de la dictadura y contextualizar el papel que desempeñaron los fotógrafos para la creación de esta primera impronta pública en torno al régimen militar, que sería retomada por distintas generaciones en su lucha por distintas tomas de posturas frente al régimen. En esto radica la importancia de la generación de documentos como el que presentamos en este artículo, en el que damos a conocer el punto de vista de los propios creadores de este universo visual a través del

${ }^{1}$ No es este el espacio para hacer una síntesis de estos cambios, pero una mínima contextualización obliga a mencionar las siguientes referencias: la negación de la represión fue evidenciada por autores como León Ferrari a través de su exposición Nosotros no sabíamos, inaugurada en Buenos Aires en el año de 1992. El llamado "show del horror", que consistió en el descubrimiento en los inicios de la democracia de distintos cadáveres de personas desaparecidas sepultados en fosas anónimas (NN) durante la dictadura, se conoció en la opinión pública de manera fragmentada a través de la prensa sensacionalista, $y$ ha sido analizada por Claudia Feld (2012); Alfonsín transitó del "Juicio a las Juntas", que puso a varios de los genocidas en prisión, a la expedición de las "Leyes de Obediencia final y Obediencia debida", que los liberó. En los gobiernos de Menem y De la Rúa la impunidad aumentó. Sin embargo, a finales del siglo pasado una ola de renovación de la memoria se expresó en la denuncia de los "vuelos de la muerte" y la creación de organizaciones como HIJos, entre otros episodios relevantes de la vida ciudadana. De manera simbólica, Néstor Kirchner mandó descolgar la foto del general Videla del Colegio Militar en los inicios de su mandato y creó las bases de una nueva etapa de recuperación de sitios de memoria y un incremento del número de juicios a los represores, que continuó en los dos mandatos de su esposa Cristina. Esta política ha creado en los años posteriores un modelo de recuperación del pasado que se diferencia de la impunidad de sus vecinos Chile, Brasil y Uruguay y, al mismo tiempo, ha generado las bases de un modelo oficial que también ha sido cuestionado por el hecho de alinear a algunos grupos de derechos humanos a la perspectiva oficial y condicionar con ello su independencia y visión crítica. Finalmente, el viraje en el tema de los derechos humanos y el desmantelamiento de las instituciones identificadas con esta bandera apenas ha comenzado bajo el nuevo gobierno de Mauricio Macri, en lo que constituye una nueva etapa cualitativamente distinta sobre estos temas.

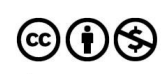


rescate del punto de vista de Eduardo Longoni, uno de los fotógrafos más relevantes del periodo.

A lo largo de este espacio nos centraremos en la etapa inicial y formativa, esto es, los propios años del régimen militar. En aquellos años, desde el lado oficial, con la cobertura de la mayor parte de los periódicos y revistas que justificaron el golpe y posteriormente reivindicaron y construyeron un imaginario mediático de orden y progreso, no tuvieron cabida el registro periodístico de las acciones y operativos castrenses de la represión ni las denuncias por las violaciones a los derechos humanos.

Sin embargo, desde otros ángulos de crítica y disidencia cívica y política, pueden observarse algunas manifestaciones, como las exposiciones de fotografía con temas tanto de protesta social como de la vida cotidiana, organizadas por los propios profesionales de la lente en distintas galerías y espacios públicos, o las tareas de colaboración entre los jóvenes fotógrafos de las agencias independientes con algunos de los grupos opositores a la dictadura, en forma preponderante, por su visibilidad pública, el de las Madres de la Plaza de Mayo (Gamarnik, 2010 y 2011).

En los primeros años del gobierno castrense, en el interior del país predominó la versión oficial de acuerdo con la cual no había personas desaparecidas por motivos políticos y en la que se declaraba que toda la propaganda contra el régimen era el resultado de la existencia de un complot internacional centrado de manera paradigmática en el boicot a la realización del mundial de futbol en el año de 1978.

Poco a poco se fueron conociendo otros ángulos, primero en el exterior a través de los organismos internacionales y el trabajo de denuncia del exilio, pero también desde dentro, con las protestas de las Madres y otros grupos de derechos humanos que pudieron expresarse en la visita de la Comisión Interamericana de Derechos Humanos de la OEA, la CIDH, realizada al año siguiente, en 1979, la cual documentó para la onu la crudeza de la represión y la existencia de centros de detención clandestina, todo ello a pesar de la presión de los militares, que trataron de boicotear y minimizar los trabajos de la Comisión.

Con este fin, los fotógrafos de distintas agencias se encargaron de realizar las coberturas de las primeras rondas de las Madres y de dar a conocerlas a nivel internacional para empezar a posicionar a este grupo, que poco a poco se convirtió en una de las referencias de oposición al discurso militar fuera de Argentina.

La aventura fallida de los militares en Malvinas y su derrota frente a Inglaterra aceleró la fragmentación del régimen y la división entre sus filas y

\section{(ㅇ)(1) $\$$}


abrió las puertas de una oposición masiva que se expresó de manera pacífica y organizada en las calles, acompañada de otro ejército, en esta ocasión de fotógrafos y periodistas que canalizaron las protestas y las demandas, precipitando la llegada de la democracia. ${ }^{2}$

En este panorama de luces y sombras, de avances y retrocesos, se ha producido la construcción de una poderosa memoria colectiva en las últimas cuatro décadas, que continuará encontrando nuevas rupturas y continuidades a lo largo del nuevo siglo con un signo distintivo cada vez más claro: la disputa simbólica generada en torno a las imágenes.

\section{LA TRAYECTORIA DE EDUARDO LONGONI Y ALGUNOS PUNTOS DE PARTIDA PARA LA LECTURA DE LA ENTREVISTA}

Eduardo Longoni nació en el año de 1959 en la ciudad de Buenos Aires. Tenía 17 cuando se produjo el golpe de Estado en Argentina en el mes de marzo de 1976. Proveniente de una familia de clase media, realizó el bachillerato en el Colegio Nacional y posteriormente estudió tres años de la carrera de Historia en la Universidad de Buenos Aires (UBA). En 1979 comenzó a trabajar en la agencia Noticias Argentinas (NA) y ahí inició un largo aprendizaje de la mano de editores tan importantes como Miguel Ángel Cuarterolo, que lo consolidaría como uno de los fotógrafos documentales y editores de fotografía más destacados de la historia reciente de Argentina. ${ }^{3}$

${ }^{2}$ La crisis económica, la inflación, el desempleo y el crecimiento de la deuda externa también contribuyeron a que la dictadura buscara una salida política y reconociera la necesidad de una transición a la democracia. En todo momento los militares presionaron antes de entregar el poder a los civiles para validar una amnistía en el terreno de las violaciones a los derechos humanos, y una vez fuera del gobierno continuaron influyendo para boicotear el avance de las reformas en los distintos regímenes democráticos. Pese a lo anterior, el gobierno de Alfonsín instaló la Comisión Nacional sobre la Desaparición de Personas, la ConAdep, la cual documentó la existencia de numerosos centros de detención, cautiverio y exterminio, con un saldo de 9800 desaparecidos, lo que implicó una primera investigación global sobre el tema a cargo del Estado, que se publicó en el informe del Nunca más, con el registro fotográfico de Enrique Shore, todo un hito en la historia de este tipo de trabajos, que tuvo secuelas importantes en los informes posteriores de otros países como Brasil, Chile, Uruguay y Guatemala.

${ }_{3}^{3}$ Miguel Ángel Cuarterolo nació en 1950 y se inició como reportero gráfico en los setenta, pero gradualmente se convirtió en uno de los editores fotográficos más importantes de la segunda mitad del siglo pasado en Argentina. Fue director de las agencias Noticias Argentinas y Diarios y Noticias en los setenta y los ochenta. Colaboró en las agencias France

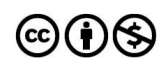


En 1981 organizó con otros colegas, como Daniel García y Guillermo Liácono, entre otros, la primera exposición de fotoperiodismo gráfico en la cual se mostraron imágenes de más de 60 fotógrafos, con una audiencia de cerca de 5000 personas que visitaron el lugar durante varias semanas, lo que constituye una referencia fundamental y un hito fundacional para el fotoperiodismo argentino de las últimas décadas.

En los años del régimen militar en los que trabajó, entre 1979 y 1983, cubrió todo tipo de actividades de la vida pública, desde los atentados guerrilleros contra funcionarios y militares hasta las protestas callejeras y las rondas encabezadas por las Madres de la Plaza de Mayo, así como una diversidad de desfiles y actos castrenses tan comunes en aquellos años.

En la propia NA se desempeñó como fotógrafo y posteriormente como editor en los años de plomo del régimen militar y durante la democracia. En el año de 1987 creó su propia agencia, EPD/Photo, para trabajos nacionales y extranjeros. Entre 1990 y 2015 se desempeñó como editor de fotografía del diario Clarín, uno de los más importantes de Argentina. La trayectoria de este profesional de la lente lo ha llevado a navegar de las aguas del fotoperiodismo a la creación de sus propios ensayos fotográficos, que ha editado en distintos libros. Uno de ellos, titulado Violencias, recupera algunas de sus fotografías más logradas durante la dictadura, al tiempo que documenta distintos episodios de represión en los años posteriores (Longoni, 2012).

El testimonio y la obra de este fotógrafo plasmados en esta primera conversación nos muestran los inicios del desempeño profesional del autor durante la dictadura. En ese lapso realizó algunos de sus trabajos más conocidos y consolidó las bases de su labor como fotoperiodista. ${ }^{4}$

La entrevista comprende los inicios de la trayectoria laboral del autor, su ingreso a NA, el contexto histórico y laboral de sus primeras entregas, el aprendizaje de los primeros años con Cuarterolo y su primera incursión como editor de la propia agencia. En el relato se describen y contextualizan algunas de sus fotografías más relevantes en torno a la dictadura, esto es, la foto de la represión a las Madres hostigadas por los militares a caballo, de 1982, la procesión religiosa de 1981 de obispos y otros jerarcas de la Iglesia en el centro de Buenos Aires, el retrato colectivo de distintos oficiales en 1981 y

Press y Reuter y se convirtió en el editor estrella del diario Clarín en la década de los noventa. Publicó con Longoni el libro El poder de la imagen, uno de los manuales de fotoperiodismo más influyentes en aquellos años. Murió en el año 2002, a la edad de 51 años.

${ }^{4}$ Esta primera entrevista con el fotógrafo se desarrolló en su departamento en el barrio de Belgrano, en la ciudad de Buenos Aires, el 16 de septiembre de 2014.

\section{()(1) $(3$}


el retrato y la documentación de la existencia de los comedores populares, mejor conocidos como "ollas", que evidenciaban el lado oscuro de la política económica de la dictadura, entre otras influyentes imágenes, que han quedado para la posteridad como emblemas de aquellos años de la dictadura.

Con la realización de esta entrevista y su publicación como documento se aporta una información muy relevante para la investigación sobre los temas de la memoria reciente. El testimonio de Longoni es importante porque nos permite contextualizar algunas de las imágenes. Sin embargo, su relevancia es aún mayor, en la medida en que nos acerca a la lógica de trabajo del fotógrafo en aquellos años y a su visión del mundo.

Una cuestión central para este trabajo ha residido en ubicar la importancia del testimonio oral como punto de partida para dialogar con el contexto visual y poder recuperar una parte significativa de la historia reciente de Argentina. Al mismo tiempo, a lo largo del proceso se presenta la imagen como un disparador de la memoria que interpela al testimonio oral y lo convoca a transitar por otros caminos.

Debido a lo anterior, a lo largo de la entrevista fuimos reconstruyendo paso a paso la trayectoria profesional del fotógrafo, deteniéndonos no sólo en los marcos políticos sino de manera particular en la propia lectura de las imágenes y en la problematización llevada a cabo por el autor sobre la captura, edición y circulación de las mismas. Se trata de un proceso dinámico en el que el fotógrafo cambia su punto de vista. Todo ello forma parte del sello particular de esta investigación, en el que, en la arquitectura del relato del fotógrafo, se prioriza el cómo sobre el qué y se enfatizan los aspectos simbólicos que subyacen en la narración, por encima de los contextos lineales o cronológicos.

Entre otras consideraciones en torno a este testimonio, cabe destacar que se trata de la descripción de los años juveniles del autor, en un tránsito muy sugerente, que permite al lector asomarse a la etapa del emblemático Colegio Nacional en los años previos al golpe, permeado tanto por la militancia de algunos de los estudiantes como por la intervención de la ultraderecha a través de algunos de los directivos. ${ }^{5}$

${ }^{5}$ Longoni ingresó a mediados de los setenta en el prestigiado Colegio Nacional, el instituto preuniversitario, de enseñanza secundaria, público y laico más antiguo de Buenos Aires. El imponente edificio se encuentra en la llamada Manzana de las Luces, en pleno centro histórico de la ciudad, muy cerca de la casa de Longoni por aquellos años. Durante los terribles años de la dictadura fue un importante espacio de crítica y reflexión. De ello dan cuenta los 105 estudiantes desaparecidos en aquella época.

\section{(이요}


Un tema central es el de las agencias fotográficas y su papel ambivalente de surtidoras de imágenes para el fotoperiodismo alineado con el régimen, al mismo tiempo que documentadoras de la represión y creadoras de símbolos para los años posteriores, con un equipo de fotógrafos que forjaron una parte muy significativa de la memoria visual argentina de aquellos años, como Carlos Villoldo, Daniel García y Marcelo Ranea.

La información en torno a la lógica y condiciones de trabajo de este perfil de profesionales, los niveles de sociabilidad y de tensión intergremiales, y por supuesto la descripción de las técnicas de revelado previas a la tecnología digital, resultan muy importantes, así como las referencias visuales más importantes de aquellos años, entre las que sobresalen figuras como Robert Frank y Henri Cartier-Bresson. En otro sentido, la entrevista permite reconstruir cierto tipo de canales subterráneos para comprender algunas de las grietas que se formaron en un universo castrense que se pretendía homogéneo y totalizador ante la ciudadanía, y que llega a cuestionar a través de la ironía la estructura de otras instituciones vinculadas al régimen, como la jerarquía católica.

Una aportación muy especial está representada por el punto de vista íntimo sobre algunos episodios muy relevantes y poco trabajados por la historiografía política de la dictadura, como es el caso de las primeras exposiciones llevadas a cabo por los propios fotoperiodistas, en el que el relato describe algunas de las tensiones que marcaron la relación de algunos de los profesionales de la lente con el poder, el aprendizaje de otras experiencias políticas y culturales, entre las que sobresale la de "Teatro Abierto", y la posibilidad de explorar espacios alternativos a la prensa convencional. ${ }^{6}$

Uno de los aspectos más relevantes de la entrevista para la construcción de una historia política del periodo tiene que ver con la alianza entre este tipo de fotógrafos y algunos actores sociales, como las Madres de la Plaza de Mayo, que llegaron a convertirse en los símbolos más importantes de la oposición a la dictadura, en parte gracias a las condiciones de visibilidad generadas por este tipo de interlocutores.

Otro aspecto no menos importante tiene que ver con el rescate del punto de vista de los editores como forjadores de la visión de una generación de fotógrafos en torno a la dictadura. En efecto, la labor de los editores influyó, a través de un complejo proceso de selección de las imágenes, en dotar de cierto

${ }^{6}$ Para una revisión aguda sobre el tema del fotoperiodismo y la dictadura, y en particular el episodio de las exposiciones de los fotógrafos durante aquellos años, véase Gamarnik, 2009.

\section{(이) $(9$}


tipo de condiciones de visibilidad a los hechos públicos y su vinculación con el horizonte político y cultural de la censura y la autocensura del régimen.

Todo lo anterior permite replantear el análisis de la mirada de estos autores desde otros lugares políticos y sociales distintos a los convencionales. La reflexión en torno a la militancia política y las distintas formas de concebirla a través del oficio posibilita también un ejercicio de contraste con otros testimonios y relatos de aquella época. El punto de vista sobre los llamados "errores" del fotógrafo marca un ángulo muy original, pocas veces explorado, de la mirada de los creadores de las imágenes, que ilustra en torno a la lectura del deber ser por parte de un fotógrafo en los ochenta del siglo pasado.

Para concluir, en este trabajo de reflexión no nos guía un ideal de fidelidad nostálgica por el pasado, ni la pretensión de revivirlo con una precisión no solamente imposible, sino indeseable. Lo que sí reivindicamos es una lectura simbólica, más atenta a las distintas posibilidades de la interpretación. Por ello, consideramos más pertinente detenernos en las marcas de la memoria de Longoni, ejercida desde la perspectiva del presente (Thomson y Freund, 2011).

\section{LA ENTREVISTA ${ }^{7}$}

\section{El inicio de una profesión. Los años de la dictadura (1976-1983)}

Tengo entendido que comenzaste formalmente en 1979. Si regresamos unos años antes, ¿cómo se definió tu inclinación hacia la fotografía?

Mi primer contacto con la fotografía tiene que ver con una revista que editábamos en el colegio secundario a mediados de los setenta. Yo hice el secundario en el Nacional Buenos Aires, que es un colegio universitario. Los que fuimos ahí le decimos: "El Colegio". Es un colegio de elite intelectual, al que llegué absolutamente de manera casual, porque mis padres eran de clase media baja y vivíamos en una casa como una especie de conventillo de clase media, con mucha familia, con la hermana de mi papá, su marido, su hija y mi abuela. Como no entraba mucha plata, en la casa había una habitación que alquilaban a una viejita, entonces, era una enorme cantidad de gente. Yo iba durmiendo,

${ }^{7}$ Esta primera de ocho entrevistas con Eduardo Longoni tuvo lugar en el departamento del fotógrafo en el barrio de Belgrano, en la ciudad de Buenos Aires, el 10 de septiembre de 2014. El conjunto total de las entrevistas será editado por el Instituto Mora en una próxima publicación.

\section{()(1) $(3$}


de acuerdo a las posibilidades que había en distintos ambientes de la casa, en un sofá. En el colegio entramos en una dictadura, que fue la del general Lanusse. Transcurrió el gobierno peronista de Cámpora, después Perón, después muere este y entra Isabel y la dictadura. ${ }^{8} \mathrm{O}$ mejor dicho, la derecha entra más rápido en la Universidad de Buenos Aires que en el país. Desde antes del golpe hay una intervención universitaria de un señor que se llamaba [Alberto] Ottalagano. [Óscar] Ivanissevich era el ministro de Educación y Ottalagano era el rector de la Universidad. Ambos salen haciendo el saludo fascista en una revista, o sea ya la derecha, la "Triple A" entra a la Universidad antes que Videla al gobierno. ${ }^{9}$

Es la etapa de José López Rega...

Claro, en la etapa de López Rega. Nosotros hacíamos una revista, que era una revista de circulación bastante restringida. Teníamos que cuidarnos de que no cayera en manos de las autoridades. Se llamaba La Voz de la Popu, y entre varias cosas que hacíamos entre amigos, esa revista se editaba y tenía entre 30 y 40 ejemplares. Empezamos a ponerle fotos, y cuando hacíamos la fotoduplicación para entregarla, no salían, no se veía nada. Entonces decidimos que íbamos a comprar una cámara, e íbamos a hacer las fotos y las íbamos a pegar, pero había que reproducir esas fotos, había que copiarlas, entonces yo hice un curso en el Foto Club Buenos Aires. Debía tener catorce o quince años. Eso me permitió saber usar la cámara, poner la película, medir la luz, revelar la película y poder ampliarla. Compramos entre todos un ampliador, las cubetas, yo que sé. Ese fue mi primer paso en la fotografía. A mí no me apasionaba en ese momento la fotografía, era casi como una actividad más de las que teníamos que hacer para hacer la revista, que sí me gustaba. Me apasionaba más el mundo del periodismo y de la historia que el mundo de la fotografía. Termino el colegio en dictadura, ya con Videla, en el 77, y hago la "colimba" [servicio militar], en el 78, que es el año de la movilización del ejército argentino hacia la frontera con Chile. Por suerte estoy cuatro meses ahí y no hay guerra. Se produce la

${ }^{8}$ En 1971 el general Agustín Lanusse sucedió al general Levingston y asumió la presidencia hasta mayo de 1973. Convocó a elecciones y entregó el poder a Héctor Cámpora en ese año. Este último convocó a nuevas elecciones y entregó el poder al general Perón en septiembre de 1973. El militar falleció el 1 de julio de 1974 y su lugar fue ocupado por su esposa María Estela Martínez, mejor conocida como Isabel.

9 La "Triple A" fue la Alianza Anticomunista Argentina, un grupo paramilitar orquestado bajo el cobijo de José López Rega, ministro de Bienestar Social del general Perón. Esta asociación ejecutó y asesinó a cerca de 1500 artistas, intelectuales y militantes de izquierda entre 1973 y 1976.

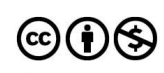


mediación de Juan Pablo II, de Samoré, toda una cuestión que hace que Videla y Pinochet paren la maquinaria bélica, y salgo de la colimba a mediados del 79 y empiezo mi carrera de licenciatura en Historia en la Universidad de Buenos Aires. ${ }^{10}$ Yo me quería ir de la casa donde yo vivía. Estaba incómodo y ya la experiencia de haber vivido una "cuasi" guerra era bastante traumática. Ya no me bancaba-como decimos los porteños-en esa casa y quería irme. Entonces, no sabía qué hacer, porque acababa de salir de la secundaria y no quería ir a hacer un trabajo de cadete. Yo quería ver si podía conseguir un trabajo que me redituara poder vivir solo. Entonces fui con mi cámara y las cuatro o cinco fotos que tenía a golpear una puerta. Había caído en mi casa una guía de medios periodísticos. Ahí estaban los teléfonos y las direcciones de los diarios Clarín, Diario, Crónica y, como solemos hacer los jóvenes, que somos un poco vagos, lo que hice es que me fijé cuál era el medio que quedaba más cerca de mi casa.

\section{El encuentro con Miguel Ángel Cuarterolo}

Yo vivía en el centro de la ciudad, y Noticias Argentinas, NA, que era una agencia de noticias, quedaba a cuatro cuadras de mi casa, en las calles de Córdoba y Florida. Entonces voy, golpeo la puerta y digo que vengo a ver a quién le podía mostrar fotos, porque yo era fotógrafo. Fotógrafo no era, obviamente, y me atiende un señor, que después fue mi gran amigo -murió hace unos años-, se llamaba Miguel Ángel Cuarterolo, que es el mejor editor que hubo acá. Cuarterolo no solamente fue el mejor editor, sino fue el que trajo la idea de los editores fotográficos a la Argentina. Antes no existía eso. Lo que había en las redacciones eran jefes de fotografía, que eran directores de tránsito que decidían qué notas se cubrían y cuáles no, pero no participaban en la puesta en página de la foto. Cuarterolo era un tipo maravilloso, muy sabio, que a mí me pareció un señor grande, pero que tenía solo nueve años más que yo, o sea, tenía 28 años, pero siempre fue un señor que se vestía formalmente, con saco y corbata. Tenía bigotes, entonces parecía un tipo más grande.

${ }^{10}$ En 1978 se produjo el llamado conflicto del Beagle entre Chile y Argentina como parte de un desacuerdo sobre la determinación de la traza de la boca oriental de dicho canal, que afectaba la soberanía de las islas ubicadas dentro y al sur del canal y al este del meridiano del cabo de Hornos. En diciembre del 78 Argentina desconoció el laudo arbitral existente entre ambas naciones y se dispuso a una intervención militar, que fue impedida por la mediación del papa Juan Pablo II.

\section{()(1) $(3$}


Yo supongo que él se apiadó de mí. Yo venía de salir del servicio militar, estaba casi pelado porque además la última maldad que te hacían en el servicio militar era que te cortaban el pelo a cero, o sea, te dejaban pelado, tenía unas fotos que eran del Foto Club y una camarita Olimpus. OM1 común, con una lente normal. Ese era todo mi equipo, ni flash, nada, no tenía nada. Y entonces yo le iba a pedir trabajo y él me miró con cara de diciendo "¿Y de qué querés trabajar?", pero se apiadó de mí y me dijo: "Mirá, vení mañana en la mañana y yo les voy a decir a los fotógrafos que empezás a salir con ellos para practicar", y agarró de un cajón un rollito "Tri x" y me lo dio. Era película rebobinada, ni siquiera era la película original. En la agencia no usaban película porque tenían algunas dificultades económicas, era una agencia pobre, más allá de que era importante en ese momento, porque todavía no existía DYN, que fue después un desprendimiento de NA y Telam, que era la agencia oficial. Eran agencias muy chiquitas, no es como ahora, que es una agencia grande, con propaganda del gobierno. En ese momento no le daban mucha importancia a la fotografía de prensa, por lo cual nA tenía los principales clientes, no solamente del interior, sino de los grandes diarios de la capital: Clarín y La Nación. Yo cargué la película y me fui a la Facultad de Historia. Al otro día, a las ocho de la mañana me levanté y fui a NA y había tres fotógrafos. Cuando salió el primero le pregunté que si lo podía acompañar. Sé que Cuarterolo se olvidó de la cuestión y no le dijo nada a ninguno, porque los tipos me miraban y no sabían ni quién era yo con el pelo corto. En esa época todo era peligroso, la gente lo desconocía a uno, no sabía, tenían una cosa de desconfianza, sobre todo que el que tenía el pelo corto, que era significado de militar, de servicio, de espía, de lo que fuera...

Como en efecto ocurrió en algunas ocasiones...

Sí. Era un sentimiento basado en algo real. La cuestión era que salieron uno, dos, tres fotógrafos y se fueron, ninguno me dejó que lo acompañara, y yo me quedé ahí con mis apuntes de historia, leyendo. Y a media mañana llegó un tipo enloquecido, como patinando, como dibujito animado, gritando: “¿Dónde están los fotógrafos?" Y yo medio le expliqué. El tipo vio que yo tenía una cámara, me agarró, me subió arriba de un taxi y me dijo: "Vámonos!" Yo venía de un colegio secundario muy politizado, con una militancia política en el Partido Comunista y con una colimba traumática, por lo que significó que obviamente además del tema de la supuesta guerra supieran que yo militaba en dicho partido. En la Argentina de ese momento los militares sabían casi todo de casi todo el mundo. Por lo cual yo era un tipo que estaba informado,

\section{()(1) $(9$}


no era alguien al que un fotógrafo le decía "vamos a tal lugar" y que no iba a preguntar nada. Yo le pregunté todo a este tipo, a dónde nos dirigíamos, de qué se trataba. Entonces el tipo, que resultó ser el subdirector de la agencia -se llamaba Jorge Brinsek-, me dijo: "Hubo un atentado a [Juan] Alemán."11 Yo sabía perfectamente quién era Alemán. Era el número 2 de Martínez de Hoz, que era el tipo fuerte del gobierno. En ese momento el orden era: Videla, Massera, que era jefe de la armada, y Martínez de Hoz. En realidad el proyecto económico fue el que dio pie al golpe. O sea que De Hoz era el personaje más importante, y Alemán era su mano derecha. ${ }^{12}$

Llegamos a Belgrano el atentado fue en la calle Zabala y Cabildo y había un cordón, no policial, sino del ejército. Había habido un atentado previamente, que fue el atentado Klein. En realidad el atentado Alemán está inscrito en lo que se llama la "contraofensiva de Montoneros", ${ }^{13}$ que es un comando de este grupo que entra -después hay una enorme discusión acerca de que a esa gente sus jefes los mandaron a morir-. Y mueren todos finalmente, pero hacen tres atentados al equipo económico, que son Klein, Alemán y Soldati. ${ }^{14}$ Después son infiltrados o los descubren y no queda ninguno. Este fue el segundo atentado. Llegamos y había un cordón del ejército. Había un montón de fotógrafos, estaban con los teles. Había un Torino Blanco, que era el auto de Alemán, que se lo veía bastante deteriorado, todo lo que puede haber después de un atentado. Yo veía el auto con el lente normal y se veía como una hormiguita. Entonces yo no sabía qué hacer, porque no solamente no conocía a nadie -porque a uno le puede pasar eso con años de profesión y no sé, si tiene una cámara le pide una al colega, o un tele y hace una foto-, pero yo no conocía a nadie y nadie me conocía a mí. Hice una foto

${ }^{11}$ Juan Alemán era el secretario de Hacienda del gobierno nacional. Su auto fue ametrallado pero él salió vivo del atentado aquel 7 de noviembre de 1979.

${ }_{12}$ José Alfredo Martínez de Hoz fue el poderoso ministro de Economía de la dictadura entre los años 1976 y 1981. Su proyecto liberal a ultranza llevó a la Argentina al desastre económico, con un incremento de la pobreza, inflación y desempleo, así como un aumento de la deuda exterior.

${ }^{13}$ La llamada contraofensiva del grupo guerrillero de Montoneros tuvo lugar en 1979 y 1980. La mayor parte de sus integrantes fueron capturados, torturados y exterminados por la dictadura.

${ }^{14}$ El empresario Francisco Soldati, padre del director del Banco Central, fue asesinado con su chofer el 13 de noviembre de 1979. Walter Klein, secretario de Coordinación Económica, sobrevivió con toda su familia a un atentado el 27 de septiembre de 1979. Un comando perteneciente al grupo de Montoneros dinamitó su vivienda. Los dos custodios de Klein murieron por asfixia bajo los escombros.

\section{(이요}


pero sabía que no sabía, digo, tenía una idea de que esa imagen que tomé era ilevantable en la ampliadora. ¡Para eso hubiera tenido que ponerlo arriba de un rascacielos para que se viera el auto! En uno de esos momentos, vi que bajó Martínez de Hoz rodeado de custodios y me metí, y en un momento un oficial o alguien del ejército me paró y me preguntó que yo quién era. Yo le respondí que trabajaba en el primer cuerpo del ejército, y que era fotógrafo. El tipo, claro, me vio pelado, Martínez de Hoz, los custodios, yo que sé y pasé, lo que me permitió hacer una foto del auto al lado, retratar a Martínez de Hoz, hacer fotos comunes. No eran grandes fotos...

\section{Pero de cerca...}

Pero de cerca. Bueno, en uno de esos momentos que estaba haciendo esas fotos se me acabó el rollo, porque los rollos estaban rebobinados. Yo no sabía de cuánto era, los rollos eran de 36, pero este se me acabó a las 20 . No tenía otro, y había perdido al tipo que me había llevado, Jorge Brinsek en el tumulto; tuve que salir por otro lado, no quería salir por el mismo lado que había entrado, porque por las dudas me pararan y me pidieran los documentos. Yo no tenía nada. En la colimba, cuando terminé, en ese momento ni siquiera tenía la baja, o sea ni siquiera había recuperado mi situación civil. No tenía documentos, porque te retenían el documento hasta que daban la baja al último soldado. Entonces había una cosa que se llamaba "licencia hasta la baja”, con lo cual tenías suspendida tu identidad, porque el documento lo tenía el ejército. Es decir, yo no tenía nada, y salí con los pocos pesos que tenía y un registro de conducir que era mi única identidad. No tenía ni tarjeta de crédito, no tenía nada. No podía volver en taxi a la agencia porque no tenía un peso. Me tomé el subte [metro]. La ciudad era un pandemónium. Te imaginás un atentado en medio de la dictadura en el año 79. La dictadura era muy fuerte en ese momento.

Llegué a la agencia como a la hora y media. Ya estaba Cuarterolo y había un clima efervescente. Era como la nota del año, y la nota del año la estaba haciendo... ¡No sabían quién la estaba haciendo! No sabían ni cómo me llamaba. Mi primer recuerdo es que cuando llegué a la agencia, Cuarterolo, que era un tipo muy circunspecto y que nunca perdía la calma, ese día lo vi perder la calma, porque me arrancó la cámara y me dijo: ¿Qué hiciste pibe?" Yo le dije: “TTomé fotos!" "Pero ¿qué tenés?”, me preguntó, y se puso a revelar el rollo. Los demás fotógrafos me miraban como diciendo: "Si tenés algo él se va a encargar de arruinarlo, porque hace mucho que no revela un rollo." Bueno, se puso a revelarlo, y cuando salió del cuarto oscuro y los negativos estuvieron

\section{()(1) $(9$}


bien, todos se pusieron a editarlos. Y no me dieron más bola. Yo miré un poco lo que había. No sabía ni lo que era una agencia de noticias, o sea, no sabía que las agencias le vendían las fotos a los diarios, le vendían los cables a los diarios de interés. Yo había ido ahí sólo porque quedaba cerca de mi casa. Con lo cual, era tal el despelote que había en esa agencia, que miré el reloj y ví que se me hacía tarde para una materia y me fui a la Facultad, y al otro día volví a la agencia. Ya ni siquiera tenía película. Caminando por la calle Florida me encontré con que la noticia obviamente era la tapa de todos los diarios, y estaba el diario La Opinión, que era un diario muy importante en ese momento, que tenía mi foto, y dije: ¿Qué hace mi foto ahí? Claro, yo no sabía qué era esta historia de las agencias que le vendían a los diarios, yo no sabía. No sé qué creía, la verdad que no sé.

Y al día siguiente viste tu foto...

Sí, y había otro diario que también tenía mi foto. Llegué a la agencia, un par de fotógrafos estaban ahí y me dijeron: “Vos hiciste la foto? Qué bueno”, y me felicitaron. Al rato llegó Cuarterolo, después llegó el director de la agencia y me ofrecieron quedarme a trabajar con ellos. Ahí empecé, esa fue mi manera de empezar. El primer día hice esa nota y me quedé hasta el año 87.

\section{Los inicios de un aprendizaje}

Obviamente tu fotografía salió sin crédito.

Diría "Foto NA"...

Pero te sirvió para quedarte ahí...

Me sirvió para quedarme, me sirvió para que de alguna manera ese fuera el ADN de mi fotografía, que tuvo que ver con la violencia política y social. Fue como mi especialidad en toda mi vida de fotorreportero y fundamentalmente sirvió para quedarme en un lugar que para mí fue "la escuela", o sea, ahí aprendí de todos mis colegas, que eran todos más grandes que yo, que eran todos muy buenos fotógrafos y muy buenos tipos. Daniel García, que es el fotógrafo de AFP en Argentina; Horacio Muchi, que después se fue a vivir a Italia; Mario Fiordelisi, que trabajó en Atlántida, y después murió; Omar Torres, que es el fotógrafo de la AFP en México; Cuarterolo, que era un monstruo como editor; Carlos Villoldo, en fin, había un montón de fotógrafos que

\section{(ㅇ)(1) $\$$}




\section{SECUENCIA}

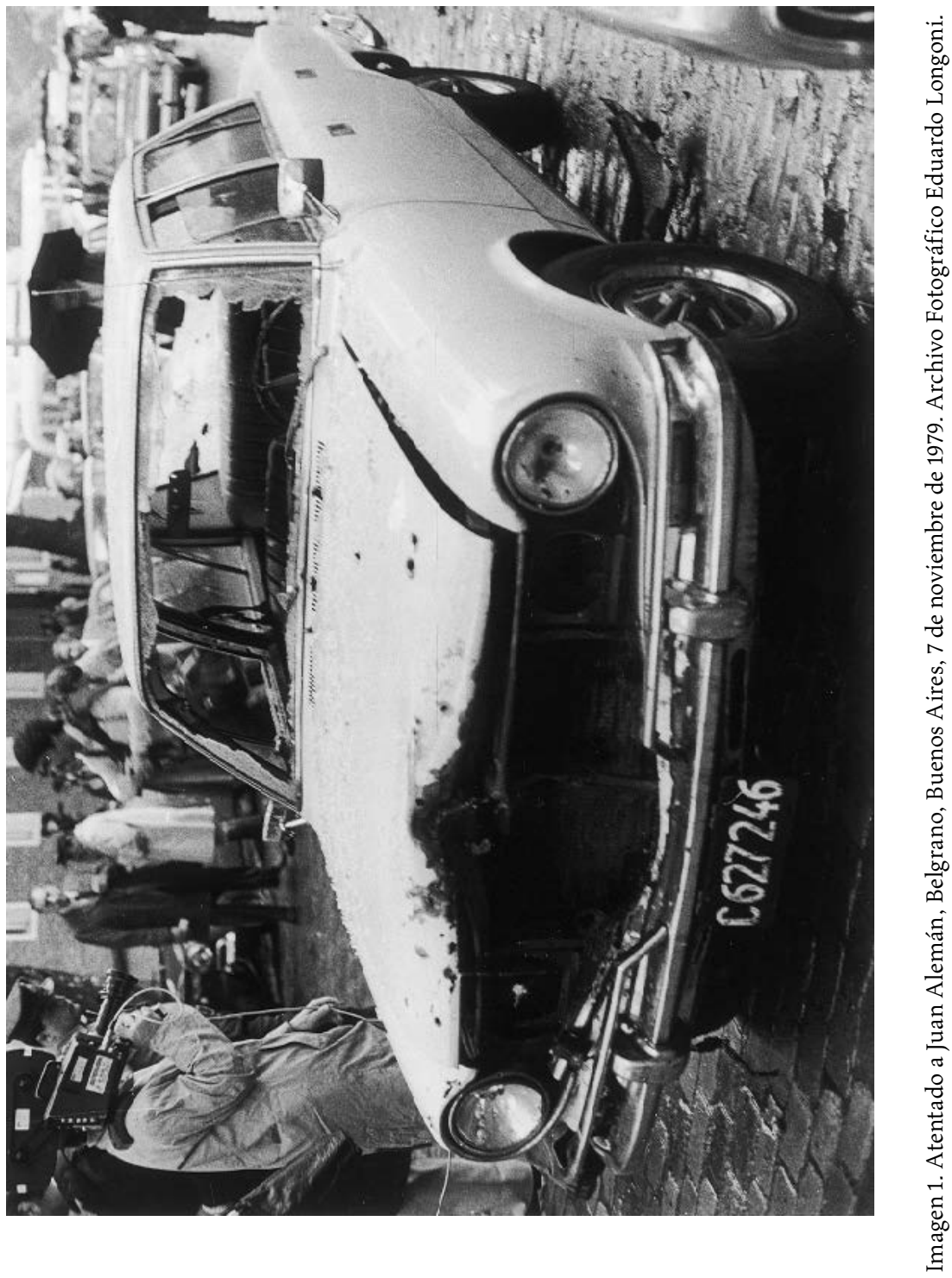

\section{(ㄷ)(1) (8)}


eran como las estrellas del fotoperiodismo en ese momento. También estaba Marcelo Ranea, el tipo gano un Rey de España, y todos eran más grandes, yo era el benjamín. La verdad que siempre me trataron bárbaro.

Era la mejor escuela posible...

Si, caí en el mejor lugar y tuve suerte, porque eso pudo haber sido una enorme frustración. De hecho, lo más lógico era que así hubiera sido, porque un chico de 20 años, que tiene una militancia política y que va a arriesgarse en medio de la dictadura a hacer una foto de un auto de un atentado, digamos que era como medio inconsciente. Que es un poco lo que tuvimos los fotógrafos de prensa en ese momento, un poco de inconsciencia para empezar a tratar de mostrar nuestras imágenes. Yo creo que había algo dentro de mí que hacía que yo quisiera mostrar, que era que mi militancia política dejaba de ser en un partido político para tratar de mostrar lo que estaba pasando en Argentina o tratar de protestar con lo que estaba pasando, creo que eso fue. No lo sabes en ese momento, pero es como el germen de lo que empieza y de lo que va a ser luego, ¿no?

Fueron años de aprendizaje...

Ahí fueron años de aprendizaje. Fueron los últimos años de la dictadura y los primeros años de la democracia, que fueron muy movidos.

En el momento en que entras a la agencia, ¿Cual fue la mecánica que te asignaron? Yo iba a la agencia y me asignaban una nota, había un jefe en la mañana, otro en la tarde, que me asignaban notas y yo las iba a cubrir. Durante los primeros cuatro o cinco meses fui colaborador, después ya fui parte del staff y tenía recibos de sueldo. De hecho, al año o año y medio ya me pude ir de mi casa, me fui a vivir con un compañero de la agencia que después entró y que era más joven que yo. Era un empleado de la agencia, o sea, tenía mi horario, pero lo que nos pasaba a casi todos era que estábamos tan apasionados por el trabajo, que vivíamos en la agencia. Yo dejé a los dos años y medio mi carrera porque no trabajaba seis horas. Yo me levantaba e iba a la agencia, si había algo importante en la tarde, me quedaba, trabajábamos a destajo, pero porque queríamos hacerlo, o sea, a nadie se le ocurría que si había que hacer una nota importante y le caía el franco, no ir, o sea, íbamos porque había una cuestión de que queríamos documentar eso. Y ahí hice todo: fui colaborador, staff, subeditor y editor de la agencia. Me fui de la agencia como editor.

\section{()(1) $(3$}


¿Al principio seguiste trabajando con tu misma cámara?

Sí. Seguí trabajando durante un tiempo con esa Olimpus. Me compré después un par de lentes más con los primeros sueldos.

\section{La marca "Cartier-Bresson"}

Las primeras cosas que me compré fueron un libro de Cartier-Bresson, un angular y un tele corto, y después, con el tiempo, me pude comprar otra cámara. Después me la robaron y la agencia me la repuso.

¿Cómo te la robaron?

Me la robaron en la agencia. En un armario, entraron y robaron varios equipos. Con el tiempo me la repusieron, me dieron en ese momento otra, seguí trabajando y en algún momento me dieron una cámara, como era la costumbre, que la mayoría de los fotógrafos de staff tenían una cámara. Era una agencia que era grande, pero siempre estaba muy ajustada económicamente.

\section{¿Y por qué Cartier-Bresson?}

Creo que el primer libro que me compré fue la antología de Cartier-Bresson, que lo tengo aquí. Es una antología que tiene todas las etapas geológicas de mi vida: tiene huellas de mate, café con leche. Lo compré porque mis colegas fueron mis maestros y ellos hablaban mucho de Cartier, y entonces yo compré el libro y no lo entendía. A mí me gustaba más Eugene Smith, porque me parecía un fotógrafo con el que me identificaba más, con la guerra, con la violencia, con contar una historia. Cartier-Bresson me parecía muy lejano, pero como ellos estaban muy enamorados de él, yo me compré ese libro, en seis cuotas, porque quería aprender, quería saber por qué les gustaba tanto, $y$ entonces lo miraba obsesivamente. A ver si me entraba, jaunque sea por ósmosis! Yo no tengo ninguna formación visual. Yo no estudié nunca fotografía, o sea, yo, que doy desde hace algún tiempo talleres de ensayos fotográficos, es una de las cosas que les advierto a las gentes que vienen: "Ustedes vienen porque supongo que les interesa mi fotografía o les interesa lo que yo puedo enseñarles para saber cómo contar con imágenes, pero no me pongan a prueba porque yo no tengo lagunas, tengo mares." O sea, hay muchos fotógrafos que yo no conozco, no los vi nunca, no tengo la menor idea, y a otros los estudié, pero todo fue de manera autodidacta y porque caí

\section{()(1) $\circledast$}


en un lugar en el que se hablaba mucho de fotografía. En los años 79, 80, acá no llegaban muchos libros de fotografía... y los libros de fotografía en ese momento eran extraños...

\section{Yeran escasos...}

¡Los pocos que habían eran carísimos! Teníamos la suerte de que había una librería a media cuadra de la agencia que estaba en Córdoba y Florida, en un entrepiso. Se llamaba Documenta, y era una librería especializada en libros visuales, de arquitectura, de decoración, de pintura, pero había algunos libros de fotografía y nosotros estábamos ahí. Nos conocía el dueño, íbamos al mismo bar, él nos dejaba hojearlos. Íbamos ahí y nos quedábamos una hora y hojeábamos los pocos que había, y de vez en cuando comprábamos uno iy todavía nos los daba a cuotas! Yo tuve una biblioteca bastante importante de fotografía, pero la fui haciendo de a poquito, interesándome y a veces entendiendo, tal vez por una miniformación universitaria, y había cosas que de entrada no me gustaban, pero si mucha gente decía que era importante, había que estudiarlas, había que verlas. Para mí estudiar un libro de fotografía es verlo mucho. En los periodos en los que entro en alguna crisis con la fotografía, agarro este libro y lo miro, y mi hija siempre me dice: “¿Otra vez estas mirando?" Pues sí... Es un poco como mi abuela, que se murió a los noventa y pico de años y lo único que leía en sus últimos 20 años era la Biblia, y había encontrado la síntesis en la Biblia. Bueno, para mí, la síntesis es Cartier-Bresson. Es mi Biblia. ${ }^{15}$

Es muy interesante que en ese momento inicial de tu vida profesional hayas llegado de esa manera a Cartier-Bresson, que es un autor con el cual has dialogado toda tu vida. Toda mi vida. Cartier ha sido como un compañero de ruta, más allá de que obviamente no lo conocí. Pero, sí, porque yo empecé y realmente es mi primer libro. Lo miraba mucho, algunas cosas me gustaban más y otras no las entendía. Después hubo un momento en que me emparenté mucho con su mirada, o sea, pasó a parecerme como "la mirada". Y creo que lo es, independientemente que después a uno le gusten otros autores y haya pasado por una

${ }^{15}$ Henri Cartier-Bresson es uno de los fotógrafos más importantes del siglo xx. Su reflexión sobre el llamado "instante decisivo" representa uno de los paradigmas más influyentes de la historia de la fotografía, y orientó el quehacer de los profesionales de la lente durante la segunda mitad del siglo xx. De acuerdo con sus planteamientos, el fotógrafo podría ser considerado como un cazador furtivo de imágenes que debía permanecer desapercibido para no intervenir en los hechos que estaba retratando.

\section{()(1) $\$$}


época de horror, donde Robert Frank me rompió la cabeza pensando en esa cuestión de la fotografía con las tripas, en vez de con la razón, o que Eugene Smith me haya gustado, y me siga atrayendo de qué manera construye su relato fotográfico, o Salgado con su primera mirada, antes de lo que yo llamo "la mirada perfecta". Yo creo que Salgado enfrió su mirada porque la hizo perfecta, y la mirada tiene que tener cierta desprolijidad. Pero Cartier-Bresson sigue siendo para mí algo así como "el" autor.

\section{Una lógica de trabajo}

También está la referencia a los trabajos de tus colegas, como otra fuente de aprendizaje.

Sí, claro. La fotografía cotidiana que iba viendo y además el tema del ejercicio. Yo me acuerdo que Horacio Muchi, que era uno de los fotógrafos, yo creo que era el mejor estéticamente, me daba ejercicios. Me decía: "Tratá de fotografiar $y$ de tener fuera de focos en los primeros planos y poner el foco en el segundo plano". Entonces yo iba y hacía cualquier nota que había: Videla, las Madres de Plaza de Mayo, cualquier cosa con ese ejercicio. Entonces él me decía: "No, por ahí no." Siempre trataba de tener una foto que sirviera para publicar, y por eso digo que ellos me trataron muy bien. Yo era como el niño mimado y, por otro lado, en esa época era reobediente, entonces había un viaje que ellos no querían hacer, había que ir al Chaco... "No: andá vos", me mandaban a mí, y yo iba, no me quejaba. Todo me venía bien, estaba fascinado, me subía a un avión. ¡No me había subido a un avión en toda mi vida! A los 22 años fui a cubrir el mundial de España y me dieron dólares. Yo venía realmente de un lugar muy abajo social y económicamente; no culturalmente, porque El Colegio Nacional de Buenos Aires me había sacado un poco de lo que era mi barrio, pero a mí el trabajo me resultaba fascinante, le resultaba fascinante a mis papás, o sea yo, a los 25 años fui a hacer una gira de Alfonsín al Vaticano y entré al Vaticano. Mi mamá no podía creer que yo entrara, yo tampoco. Para mí ese momento fue de mucha construcción, de aprender mucho. Y por otro lado, también de mucha fascinación. Y una de las cosas que ahí hay es una génesis, ahora lo puedo decir, después de tantos años. En algún momento yo dejo de ir a la Facultad porque ya no puedo más. No sé, preparaba un parcial y el día que lo tenía que presentar en la Facultad, estaba en Quito, en un partido de la Copa Libertadores. Me mandaban a mí porque nadie quería ir.

\section{(1)(1)}


De alguna manera dejo de estudiar los documentos para intentar producirlos y una de las cosas que hice, que fue tal vez una de las diferenciaciones con mis colegas de ese momento, es que me guardé el material, siempre fui superprolijo con guardarme las cosas. O guardaba una copia o guardaba un negativo que me interesaba. Y si había que revelar y fijar rápido, porque había que meterla en el servicio rápido, yo después sacaba el rollo y lo fijaba de nuevo, lo lavaba, y si había una foto que me gustaba, me cortaba el negativo y lo guardaba.

¿Y cómo era esa lógica de trabajo en esos primeros años? ¿Te asignaban una tarea, tomabas tus imágenes y revelabas?

Cada uno revelaba sus fotos y las copiaba, porque la agencia lo que hacía en ese momento era: copiaba una foto 20-25 y hacía el epígrafe, y esa foto se transmitía en los viejos transmisores de telefotos, que se llamaban S-16, que era un cilindro donde se ponían las fotos y una cédula fotoeléctrica que leía la escala de grises y la decodificaba en un receptor en el diario del interior y después la revelaban. Entonces tenías la radiofoto. Había muchos diarios que eran de la capital o del Gran Buenos Aires. Iban los motociclistas a retirar la foto de lo que nosotros llamábamos "el palomar" que era un mueble que decía, por ejemplo, "Clarín" y ponías las fotos del servicio. Se supone que había ocho notas, entonces pasaba el motociclista y se llevaba las fotos.

Eso en cuanto a las copias, ¿y el negativo?

El negativo se quedaba en la agencia. A veces se quedaba en la casa de uno, digamos. Bueno, esa fue la manera como se salvaron muchas fotos, porque en las agencias hicieron estropicios. Yo todavía hoy sigo lamentando no haber sacado más, no haber sacado todo, porque lo que estaba ahí se perdió...

Y de esos negativos que revelabas, ¿quién hacía la primera selección para ver cuáles copias podían publicarse?

Lo hacía el editor.

¿Tú lo revisabas con el editor?

Claro. Había tres editores en ese momento. Cuarterolo era el jefe, Daniel García era el segundo y Carlos Villoldo era el tercero. Entonces siempre había un editor durante cualquier turno en el que vos estabas, y el editor era el que marcaba la foto. En un megatoscopio revisaba los negativos, fueran uno, dos o tres rollos o los que habías hecho, y te decía: "Copia esta y esta." A veces era una

\section{()(1) $(3$}


sola foto y la copiabas. Aprendía mucho de laboratorio, porque había como 20 diarios a quien copiarle, entonces hacíamos tal vez 20 copias de cada foto.

Entonces aprendías por un lado la cuestión técnica del laboratorio, y por otro lado aquello era un taller de edición de lujo para ti.

Sí. Me interesaba mucho. Yo era una esponja aprendiendo, jera como un nene de la Villa 31 en Disneylandia!, o sea, yo había salido de un lugar a golpear la puerta para ver qué y estaba ahí adentro y me daban bola. ${ }^{16}$ Me alentaban, bueno, habría alguna cosa que tendría que ver con la voluntad y otra cosa que tendría que ver con algunas miradas. Yo no sé de dónde había mirado mucho, porque yo no sabía nada de pintura, no había mirado mucho cine, no tenía una mirada muy entrenada. Creo que la empecé a entrenar ahí como una locomotora, o sea, miraba mucho todo el tiempo. Y claro, era un taller en el que aparte te pagaban. Un tipo como Cuarterolo, que era un Zar, una eminencia, no te decía: "Esta foto." Él te decía: “¿Y por qué esta foto?", o "vamos a elegir esta porque hay que dar una foto, pero no me gusta cómo la hiciste, tendrías que haberte puesto a la derecha, a la izquierda”.

Una de las cosas que yo aprendí en los negativos y lo hice cuando pasamos a la fotografía digital es: "No me edités vos, déjame." El negativo o la tarjeta es la radiografía de cómo te moviste en la nota, y muchas veces Cuarterolo me decía: "Acá te tendrías que haber parado, pero vos seguiste, acá te debiste de haber parado, este era el meollo de la cuestión y deberías haber mirado para acá, bueno no sé, esta es la mejor, pero no está buena.” Eran muy exigentes. Yo me iba muchas veces a mi casa medio "depre", porque te cagaban a pedos todo el tiempo. Y además porque yo entendía que estaba aprendiendo. No me la creí nunca, la verdad que no me la creí nunca, porque me parece que hay una cuestión, que mi oficio lo que tiene es la construcción hormiga de las cosas que vas haciendo, o sea, yo me siento orgulloso de lo que hice, pero me parece que tuvo que ver con la voluntad, con buenos lugares de aprendizaje, que después lo replicamos en Clarín, porque Cuarterolo después se hace editor de Clarín y me lleva a mí como su segundo jefe ahí años después.

Creo que eso también me llevó a mí a participar activamente. Yo quería todo el tiempo trabajar. Entraba en ese momento a la agencia a las ocho de la mañana y me pasaba ahí todo el día. Me levantaba a las siete e iba a la

${ }^{16}$ La Villa 31 es un barrio marginado ubicado en el barrio de Retiro de la ciudad de Buenos Aires. Surgió en 1932 y actualmente es el asentamiento ilegal más emblemático de la ciudad, situado a escasos metros de los barrios más cotizados, como Recoleta.

\section{()(1) $\$$}


agencia. De ocho a dos era mi horario de trabajo, pero también el sueldo era bastante magro, entonces hacíamos algunas horas extras, y si no hacíamos horas extras, nos quedábamos igual. Porque si no estaba la muestra, estaba algo que me interesaba, o me iba a hacer una nota porque me gustaba. De hecho, el mundo para mí era la agencia. Yo alquilé mi primer departamento a medias con un compañero de la agencia. O sea, todo era eso. Y nos íbamos a almorzar y a cenar con la gente de la agencia: eran mis amigos, más allá de que yo tenía mis amigos de la escuela secundaria. Yo estaba encantado con esto, era como haber llegado al paraíso rápidamente.

\section{Las Madres de Plaza de Mayo ${ }^{17}$}

Uno de los símbolos más importantes de la lucha por los derechos humanos y contra la dictadura es el de las Madres de Plaza de Mayo...

Mi primer contacto con las Madres fueron las marchas de los jueves a las tres de la tarde, que eran las marchas que se hacían. No sólo las cubríamos casi todos los jueves e íbamos y hacíamos fotos, ellas venían después a la agencia, nosotros les dábamos algunas fotos, siempre, eso fue una constante. A veces le tocaba a uno, a veces a otro. Nosotros trabajábamos mucho, aunque no nos tocara. Tal vez iba a haber una marcha grande que era especial porque era un aniversario, y aunque a mí no me tocaba ir, yo íba y hacia fotos igual, y las revelábamos, y también si había una foto distinta se publicaba y se mandaba. La relación con las Madres era de mucha confianza. Con Nora Cortiñas tenía una relación entrañable. ${ }^{18}$ Ella venía, nos cuidaba, a veces se preocupaba por si habíamos llegado bien a casa, ella nos llamaba a la Agencia por si había una marcha que terminaba en represión. Siempre fue una relación muy entrañable, porque también formaba parte de una cuestión ideológica, yo tengo amigos desaparecidos, con lo cual había madres de mis amigos que tal vez eran

${ }^{17}$ Las Madres de Plaza de Mayo constituyen uno de los principales grupos de oposición a la dictadura y uno de los símbolos icónicos más influyentes a nivel internacional. Se formó en los años del régimen militar y sufrió la represión constante del mismo. Su objetivo principal fue la lucha por rescatar a los desaparecidos y configurar el secuestro de los mismos como un crimen de lesa humanidad que no prescribe.

${ }^{18}$ Nora Cortiñas es una de las creadoras del grupo de las Madres de Plaza de Mayo. En 1978 este grupo se dividió y Cortiñas inició el grupo Línea Fundadora, que reivindica el uso de las fotografías en las rondas y protestas de las Madres, así como el rescate y la mención del nombre y la identidad de cada uno de los desaparecidos en la realización de cada una de las rondas.

\section{()(1) $(3$}


Madres de Plaza de Mayo, entonces había una comunión. En ese momento no había diferenciación política, de un tipo que venía de la izquierda, un peronista, un radical o un demócrata cristiano. Todos estábamos en contra de la dictadura, entonces era más fácil: estabas en un bando. Nosotros sabíamos mucho de esta historia, que muchas de las fotos que nosotros podíamos sacar tal vez no se publicarían en los medios, pero sabíamos que eran importantes para ellas, entonces muchas veces ellas venían, después de las marchas, y nosotros ya habíamos copiado las fotos y les dábamos una o dos fotos. Más allá de que la agencia no nos reprendía por eso, tampoco era que nosotros podíamos agarrar una caja de papel y copiarla. Entonces ellas se llevaban algunas fotos. Esas imágenes empezaron a circular en Europa, mostrando las protestas, lo que pasaba los jueves, ellas llorando, los pañuelos, etc. Y entonces ahí se generó un ida y vuelta donde a mí me termina emocionando mucho lo que ella dice, que es que ellas estaban preocupadas por nosotros. ¡Nosotros estábamos preocupados por ellas y les dábamos las fotos, y ellas estaban preocupadas por nosotros porque teníamos la edad de los hijos que les habían arrancado!

En ese momento no había diferenciaciones políticas, no importaba que una madre fuera la madre de un militante, de un montonero o un obrero o un estudiante o un dirigente barrial, digo, era lo mismo. Todo mundo estaba contra la dictadura. El enemigo era más claro. Había una cohesión política y una coherencia política contra eso. Después terminó habiendo divisiones, pero en ese momento era superclaro. Nosotros fotografiábamos todo lo que tuviese que ver con los organismos de derechos humanos. Tratar de sacar - estamos hablando de una sociedad donde no había internet, ni teléfonos celulares- las fotos para que se vieran en algún lugar, había que llevarlas. Le dábamos muchas veces fotos a las agencias internacionales y empiezan a transmitir fotos de las Madres a la UPI. Si había un episodio que nosotros teníamos, les dábamos las fotos, ni siquiera sé si había una transacción comercial, si la agencia se las vendió o se las dábamos, yo lo que me acuerdo es que nosotros nos sentíamos superorgullosos de que la moviera una agencia internacional, porque era nuestra foto.

Así cubriste algunos episodios que se han convertido en iconos de la lucha de las Madres.

Creo que la foto más conocida es la foto de los caballos, la cual ganó un premio importante en Moscú en ese momento. Yo gané el premio y esa foto se publicó mucho. Estamos hablando ya después de Malvinas, es la Marcha por la Vida, en octubre del 82, cuando la grieta de la dictadura es más grande.

\section{()(1) $\$$}


Ahí en general ya había habido varias represiones a marchas obreras, pero era muy difícil concebir la represión a las Madres. En la dictadura, la policía en la calle, e incluso el ejército, se cuidó de no pegarle a las Madres, y esa es una foto donde le están tirando la caballería a dos Madres, por eso fue una foto que se publicó mucho, porque era como el colmo.

Leí una reflexión tuya en el libro En negro y blanco sobre esta foto en particular, en la que te referías al hecho de que el fotógrafo está acostumbrado a trabajar en una zona de confort, pero que ahí perdiste tu zona y estabas...

En el medio...

Exacto: en el medio, y por lo tanto, muy vulnerable, y eso te dio un encuadre y un enfoque distinto de las cosas.

Sí, yo una vez dije en una charla -después me arrepentí porque me pareció medio banal- que yo salí de la calle invicto, en el sentido de que nunca me pegaron un palazo, o un balazo de goma, y estuve preso una vez, pero por una boludez: un día perdí la chaveta y en un incendio le tiré la gorra a un policía, pero nunca en una situación de despelote social. Entonces, muchas veces son reflexiones sobre lugares que ocupé en esos momentos, y yo creo que lo que vos decís se refiere a esa situación de las Madres de Plaza de Mayo. Fue una situación, yo diría que de cierta torpeza fotográfica, y es que me metí en un lugar donde no debería de haberme metido, casi en el medio de los caballos y las Madres, y además tengo el recuerdo sensorial de haber apretado muy fuerte el disparador cuando no había que apretarlo. Uno no hace una foto mejor por apretarlo fuerte, pero lo hice porque sentí una bronca que no sentí nunca antes. Nosotros cubríamos mucho a las Madres, las represiones, las marchas de la resistencia. Hay un programa que se hizo este año y que se llama CQC. Al final habla Nora Cortiñas. Y ella dice una de las cosas que fueron importantes y que tenían que ver con esta cuestión de la militancia política, porque el lugar donde yo estoy son todos tipos que no militaban en política pero tenían una clara militancia contra la dictadura. Nosotros fuimos los primeros que empezamos a dar fotos a las Madres para que ellas las mandaran afuera. Son las primeras fotos que se empiezan a ver en París. En el 78, en pleno mundial, se empiezan a ver las cosas que pasan en la Argentina, que tienen que ver con la calle, porque hay una cosa que yo siempre explico a los que no vivieron en Argentina: que así como la dictadura chilena de Pinochet convirtió el Estadio Nacional en un campo de concentración y dejó que lo fotografiaran, en la Argentina no hay una sola foto de

\section{()(1) $\$$}




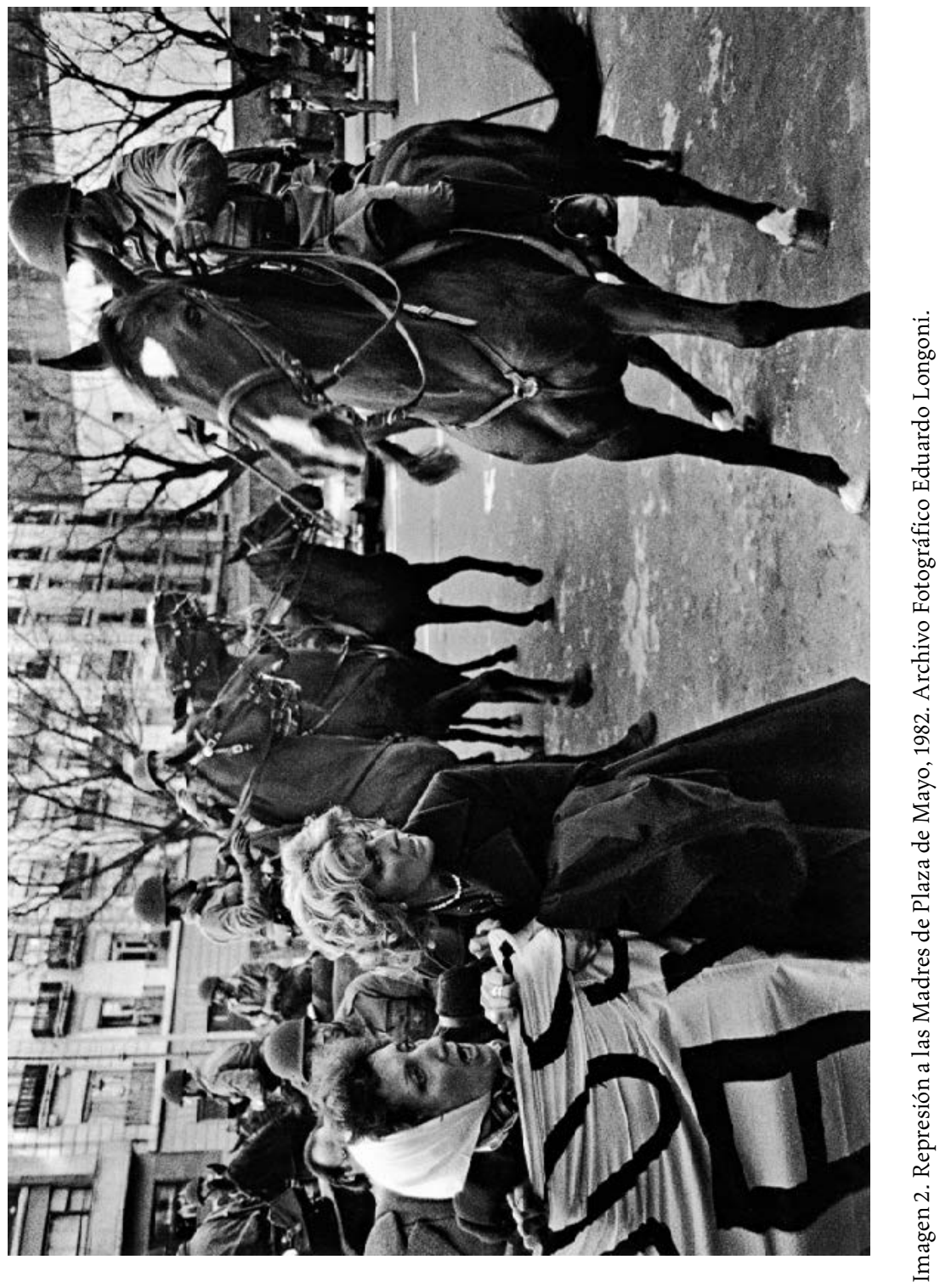

\section{(ㅇ)(1) $\$$}


un secuestro, ni de una sesión de tortura, no hay fotos de los desaparecidos o tirados del avión, o sea, lo que nosotros hicimos en ese momento fueron fotos que se transformaron después en símbolos.

Los "errores" de un fotógrafo

Muchas veces me preguntaron por qué razón no había cubierto alguna guerra, y yo he explicado que a mí no me interesa la foto de la violencia por la violencia, sino que lo que me interesa es tomar partido. Y yo tomé partido. Era un militante político con una cámara, para mí había un enemigo, que era la dictadura, y había un proyecto a empujar, que era la caída de la dictadura. Entonces, para mí ir a Siria y fotografiar las tropas del presidente sirio o a los chiitas, me da lo mismo, pues no sé quiénes son los "buenos" y cuáles son los "malos". Lo puedo mirar, pero yo siempre fotografié para decir algo, para opinar. Para mí la cámara era un vehículo, y tenía claro que si quería pelear contra la dictadura no podía pelear con las mismas armas que un manifestante, sino que tenía que pelear con mi cámara, y entonces no podía tener el lugar del manifestante. Yo creo que en esa foto de los caballos tengo el lugar del manifestante, porque me desubiqué, era también joven, pero hay fotos previas de despelotes y demás en donde yo tengo una mirada más inteligente, que es la mirada de preservar el documento, de poder hacer la foto. Y ahí me expuse a ser atacado por la caballería, bueno, de hecho me atacó, y me caí. Todo fue un despelote, igual fue en un segundo, pero yo me acuerdo de esa escena porque me llevó a reflexionar que eso había sido un error, más allá de que hay algunas fotos que uno saca que son interesantes y que resultan a partir de un error. Yo tengo que buscar una posición que me preserve lo más que se pueda de la situación de violencia, de la de guerra. A veces no hay una situación que te preserve, pero no puedes entrar y salir de la escena como Pancho por tu casa, pues están pegando de verdad, no es una obra de teatro.

Y en esas fotos tienes la perspectiva del manifestante...

Sí. Estoy metido como un manifestante más. Por eso la foto y el ángulo de la lente que yo usé en ese momento tiene esa violencia y esa cercanía casi de desesperación. Yo creo que esa foto, tal vez, no sería la misma, obviamente, no sería la misma, si yo hubiera estado dos pasos más atrás, con una lente que la acercara más, pero me hubiera preservado en la situación del fotógrafo, no del manifestante. 
¿Te acuerdas que lente usaste?

Claro, un 24.

\section{La otra cara de la dictadura}

La agencia, además de tener algunas cosas que publicaba de sociales, lo fuerte era la cuestión política, o sea, los actos militares, que había muchos y que a mí me tocaron en los primeros años de la dictadura porque trabajaba en la mañana, y los militares siempre lo hacían en la mañana, y también las coberturas sobre los organismos de derechos humanos, las protestas sindicales que se empiezan a ver en ese momento, las ollas populares, toda una cuestión también que empieza a ver cuando empieza a resquebrajarse la situación económica a partir de 1981.

¿Te refieres a las ollas como comedores populares?

Se llaman "ollas populares". Empieza a hacerse notar esto, es una cosa que la dictadura no quería que se viera. Era la pobreza. El plan económico de Martínez de Hoz era un plan de sustitución por importación, o sea, cerraban las fábricas, el dólar barato, traían todo importado y entonces no había trabajo acá. Ese es el plan, digamos, exportar granos. Martínez de Hoz provenía de una familia ganadera y de terratenientes, exportar materia prima y cerrar las fábricas y traer todo importado. Cuando eso también se empieza a dar, la cuestión social, es una cuestión que los grandes medios son reticentes a publicar en ese momento y la agencia empieza a buscar esa temática.

Para mí también fue una sorpresa encontrarme con que a diez cuadras de la Casa de Gobierno había ollas populares. Las iglesias que no pertenecían a la jerarquía eclesiástica le empiezan a dar de comer a la gente que estaba muriéndose de hambre.

Ese es un tema difícil para hacerlo circular, no tiene este perfil más atractivo de las Madres o que puede tener la violencia en general, que vende más.

Sí. Era más difícil, por lo cual se publicó menos. Se hacía, pero era menor el impacto que tenía. El pañuelo de las Madres terminó siendo el símbolo de lucha contra la dictadura y ahí estaba involucrado todo, la lucha contra la dictadura, los derechos humanos y los desaparecidos, pero también la cuestión económica y la pobreza. Las Madres fueron la punta de lanza que empezó a derrumbar los cimientos de la dictadura, el pueblo terminó derrumbando la

\section{(ㅇ)(1) $\$$}




\section{SECUENCIA}

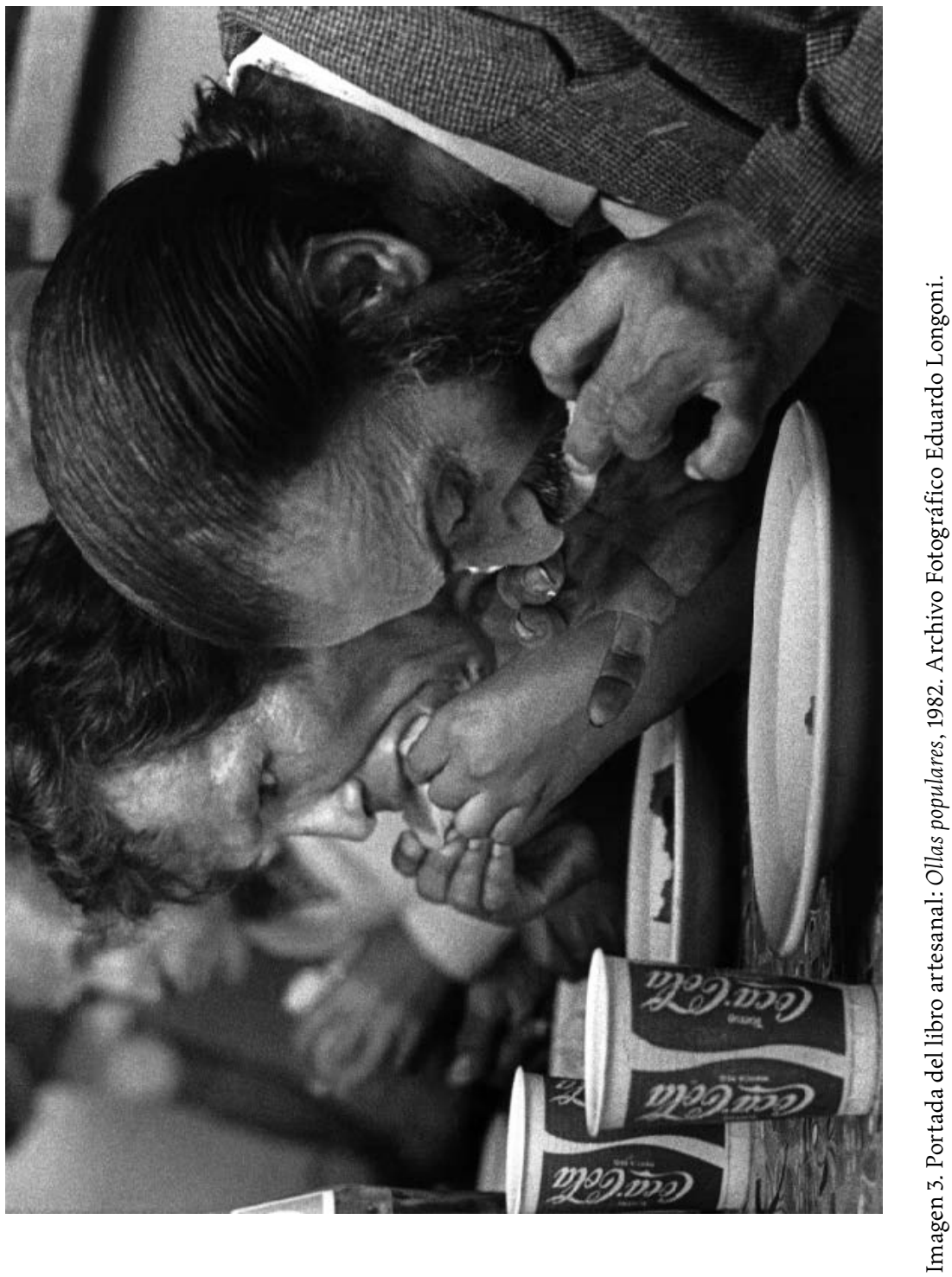

\section{(ㄷ)(1) $(8$}

Atribución-NoComercial 4.0

internacional (CC BY-NC 4.0) 
guerra de las Malvinas, pero la guerra es una guerra desesperadamente buscada para cohesionar a la sociedad argentina. No se les ocurrió hacer una guerra porque sí. Sólo en la cabeza de un borracho como Galtieri se podía cohesionar a la sociedad argentina con la guerra. De hecho lo empezó a lograr al principio, pero bueno, tenía patas cortas después que había soltado la guerra. ${ }^{19}$

\section{Los símbolos del régimen}

La dictadura argentina esta fotografiada en símbolos. Una de las cosas que yo cuento es la foto de Videla rezando. Muchas veces me han preguntado que cómo hice esa foto. Me animé a hacerla porque era la cosa más fácil del mundo, o sea, estaba a dos metros del tipo, me quedé un montón de tiempo haciendola, porque los custodios de Videla pensaban: "Este pibe está haciendo una foto de nuestro presidente rezando en una iglesia, ¿qué tiene de malo?" Mi sensación es que esa foto iba a tener una resignificación después, porque estaba claro que Videla era un asesino y estaba claro que esa imagen que en ese momento podía servir para lo que era...

\section{Para propaganda...}

Ni siquiera para propaganda, sino sólo como una foto del momento. Iba a ser una foto que después tuviera otra connotación, la de la convivencia entre la dictadura y parte de la jerarquía eclesiástica.

La foto de los militares mirando a la cámara es una foto que no se publica en ese momento. En esa foto salía el ejército. Yo fui a hacer una foto de un general hablando, no me acuerdo ni quién era. Y jugando después -hasta creo que éramos inconscientes de lo que estábamos viviendo en ese momento-, me di vuelta y vi, estaba con un tele, con un 200 , y vi esas caras e hice esa foto, que además tiene una veladura por esos rollos rebobinados que teníamos. Las fotos yo las copié en ese momento. Nadie iba a mover esa imagen, ¿qué decía esa foto? Yo me la guardé. Y dije: "Esta foto..." Y cuando la dictadura empezó a resquebrajarse yo comienzo a publicarla, a mandarla a alguna muestra, y después se convirtió en un símbolo, en el símbolo de

${ }^{19}$ El general Leopoldo Galtieri fue presidente de facto en Argentina entre 1981 y 1983. Sucedió en el puesto al general Viola y le tocó organizar y presidir la fallida recuperación de las islas Malvinas, que aceleró la derrota y el desprestigio de los militares.

\section{(ㅇ)(1) $(2$}




\section{SECUENCIA}

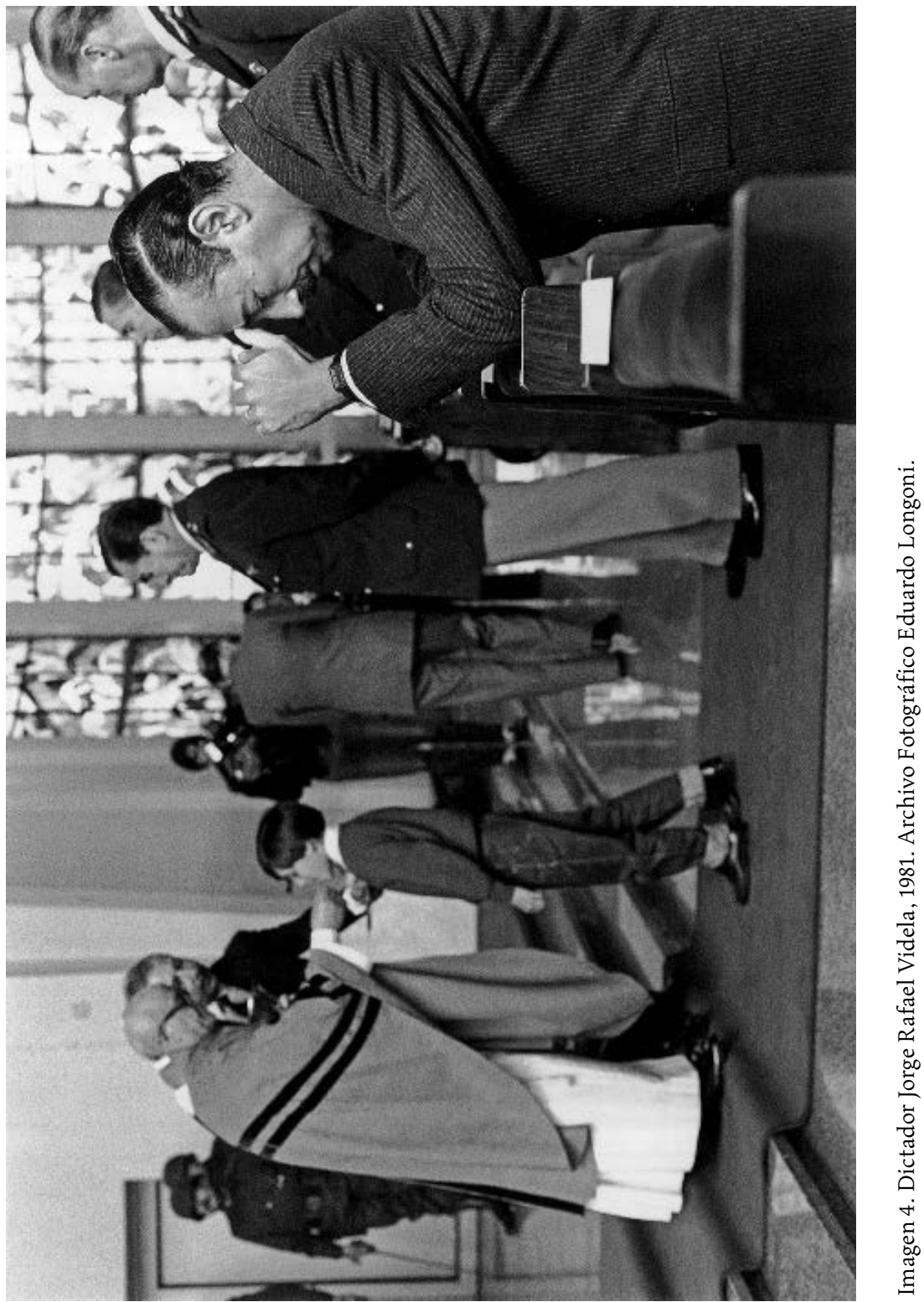

\section{(ㄷ)(1) $(8$}


la dictadura. Se convierte en el Partido Militar, como si en ese rectangulito cupiera lo que fue la dictadura.

¿Intuías en ese momento que esa misma foto podría tener otras lecturas después? Yo tenía una cuasiformación histórica. Me había gustado la historia, había estudiado dos o tres años de historia, pero mi colegio secundario le había dado mucha bola a la historia, tuve muy buenos profesores, entonces yo podía entender que el gobierno militar se iba a caer en algún momento, que esos pequeños recortes, no solamente míos sino los de mis colegas, tenían alguna significación.

\section{Las primeras exposiciones del fotoperiodismo gráfico argentino}

¿En qué contexto se da tu primera exposición?

En el 81 hicimos la primera muestra de periodismo gráfico. Yo soy uno de los fundadores y era un nene, empecé a finales del 79 y la muestra fue en 81 , o sea tenía sólo 22 años. Era uno de los impulsores porque entendía que había que mostrarlo, que eso había que llevarlo a la gente, ya que en los medios no podía publicar.

Ahí tuviste un papel importante, junto con otros colegas.

En ese momento el grupo de fotógrafos que empezamos con esa idea de mostrar lo que no se publicaba demasiado en la prensa éramos socios de la Asociación de Reporteros Gráficos, pero no miembros de la comisión directiva, y veíamos a la gente que lideraba la asociación como gente un poco demodé, más veteranos, que no tenían muchas ganas de comprarse problemas con el gobierno en turno. Ellos habían conseguido un premio, en un concurso de fotografía deportiva, donde el primer lugar era un auto, jun auto! O sea, nada más y nada menos que un auto -nosotros al auto nos subíamos cuando era un taxi-. Pero nosotros no queríamos eso. Queríamos hablar de fotografía política, que no se podía mostrar en los medios. Entonces, por eso nos llamamos Grupo de Reporteros Gráficos. La Asociación de Reporteros Gráficos recién toma para sí la muestra años después, cuando nuestro grupo se hace cargo de la asociación. De hecho, en estos últimos años, el que organiza la Muestra de Periodismo Gráfico Argentino es la Asociación de Reporteros Gráficos. Pero en ese momento no lo era. En ese momento era un grupo que no tenía líderes, que no tenía un presidente, sino que era un grupo de trabajo

\section{(이요 $\$$}




\section{SECUENCIA}

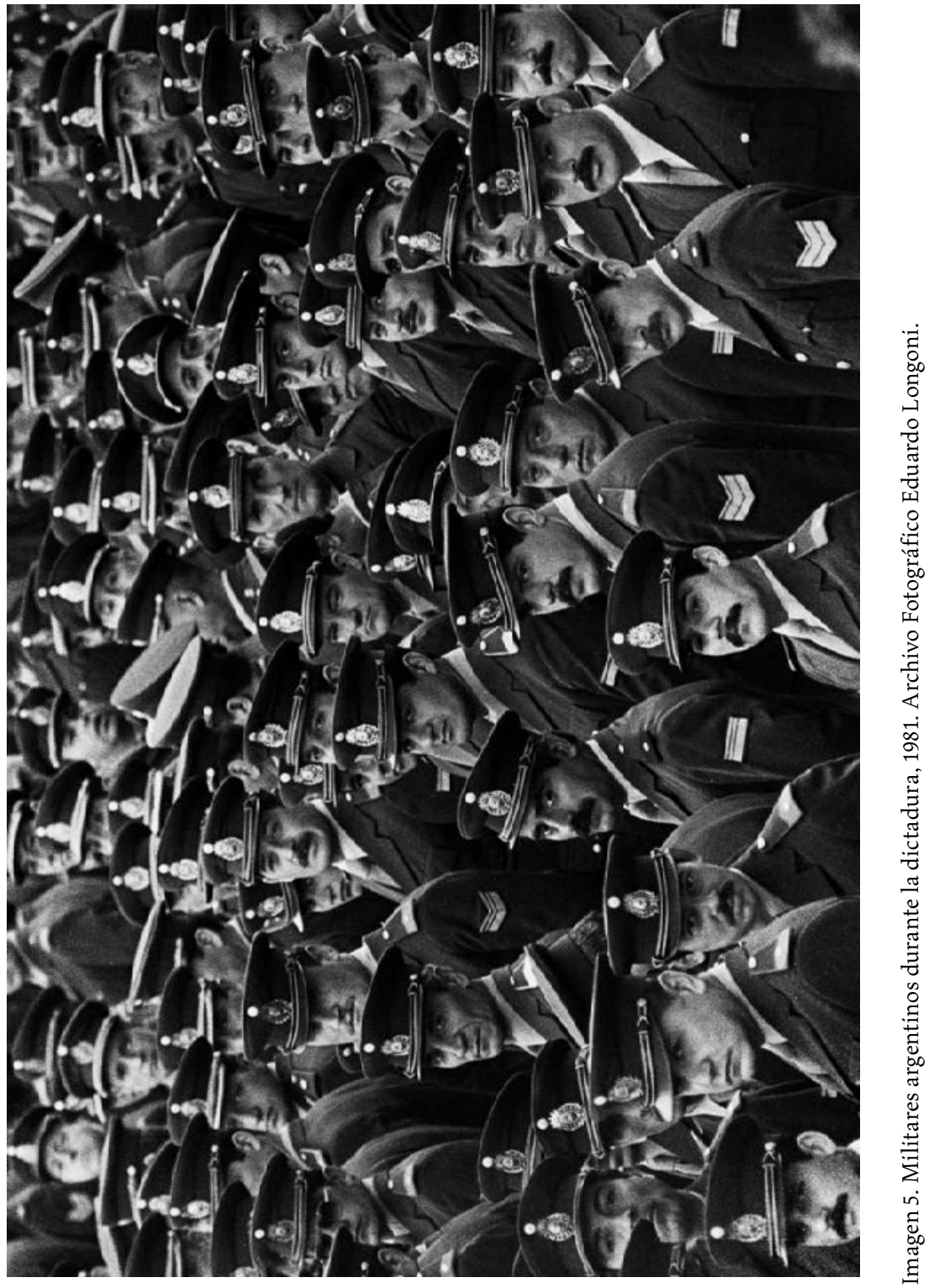

\section{(ब)(1)}


muy horizontal, que estaba muy centrado en Noticias Argentinas, que era la agencia donde yo trabajaba. La mayoría de la gente que trabajaba en ese grupo era de NA. Había un par de fotógrafos de Clarín. De los que yo me acuerdo que trabajaban en eso, estaban Leonardo Zavattaro y Becquer Casaballe, que eran de Clarín. Había gente de Perfil, estaba Rudy Hanak. Había un fotógrafo que era independiente en ese momento, que tenía un laboratorio que fue donde se hizo la primera reunión, y se llamaba Aldo Amura. Él puso en su laboratorio el lugar físico para la primera reunión. Y había algunos fotógrafos independientes. Nosotros empezamos, pero el centro, donde se recibían las fotos, donde retocábamos las fotos, donde hacíamos las fotocopias para una gacetilla y demás, era NA. Todo se hizo en la redacción de NA, todo quiere decir: se mandaba la foto, nos encargábamos de cortar los papeles, retocar las fotos que estuvieran mal, que tuvieran basuritas, etc. ¿Me imagino hoy un fotógrafo retocando gratis la foto de otro? No. En ese momento nosotros queríamos que quedara bien. Le teníamos tanto amor a nuestras propias fotos como a las de nuestros colegas. La primera muestra se hace en el Centro de Residentes Azuleños, que es un lugar que no recuerdo quién consiguió. Azul es una ciudad de la pampa húmeda en la provincia de Buenos Aires. No sé por qué había un Centro en Buenos Aires, pero lo tenía, estaba en San Telmo. Ahí fuimos con la primera muestra, no teníamos marco, no teníamos nada. O sea que pegamos las fotos en paspartú. Me acuerdo que era un día de humedad y se doblaron. Era, desde el punto de vista estético, impresentable. Pero desde el punto de vista político y fotográfico era una explosión de imágenes. Pudimos hacer un desplegable (no hicimos catálogo) y un dibujante nos hizo una lechuza. Esto viene de una cuestión de anécdota futbolera, que es que los hinchas de los equipos que están atrás de los arcos, cuando uno está atrás de la portería que defiende su arquero, nos decían a los fotógrafos "lechuzas", porque estábamos ahí como aves de mala suerte porque le iban a hacer un gol a su equipo. Y ahí, bueno, la fotografía deportiva, independientemente de nuestros intereses, nos convocaba a todos (todos íbamos los domingos a la cancha), porque el futbol, en ese momento, y ahora también, era muy convocante: los medios ponen muchas fotos de futbol. Entonces, bueno, ese fue como el símbolo de los reporteros, y él nos hizo ese dibujo.

Fue muy sorpresivo. Hay que tener en cuenta que el antecedente cultural en el cual nos basamos fue en "Teatro Abierto". ${ }^{20}$ Fue una explosión de

20 "Teatro Abierto" fue un movimiento cultural iniciado contra la dictadura militar y fundado en julio de 1981. Tuvo una gran influencia en la sociedad. Inició en el Teatro del

\section{()(1) $(9$}


distintas obras de teatros que se hicieron en lugares alternativos, y era tratar también de mostrar lo que no se podía mostrar. De hecho también incendiaron el teatro donde se iba a hacer la inauguración de "Teatro Abierto", llamado El Picadero, y nosotros nos basábamos en ese hecho de "Teatro Abierto", que es esa primera protesta cultural contra la dictadura y estamos un poco montados sobre eso, aprendimos de la experiencia de "Teatro Abierto", en mirarlo, pero para nosotros fue muy sorpresiva la recepción el día de la inauguración de nuestra expo. No lo podíamos creer.

¿En qué año fue?

La primera muestra fue en el 81 . Y después las dos muestras subsiguientes, 82 y 83, fueron en un edificio que estaba en Avenida de Mayo, al 700, que era un edificio de la OEA, pero que dependía del Ministerio del Interior. En el 82 pudimos hacer la muestra ahí, más allá de que el Ministerio del Interior era de la dictadura. Pero en el 83 nos prohibieron hacer esa muestra, que es la muestra clave del periodismo gráfico argentino. La más convocante, donde hubo colas para entrar y donde empezamos a entender el poder que tenía nuestra fotografía. Yo creo que la del 81 es un hecho de rebeldía, el 82 es un año raro dentro de la dictadura. Está la guerra de Malvinas, que parte un poco la dictadura en dos pedazos, ¿no? A partir del 82 la dictadura empezó, de alguna manera, su retirada. Seguía habiendo desaparecidos, seguía siendo un gobierno muy complicado desde el punto de vista de represión. Hay tal vez más represión en la calle, porque la gente sale más. Tal vez hay menos desaparecidos de lo que implicaba el secuestro selectivo de militantes políticos, obreros, estudiantiles, pero empieza a haber más represión en la calle porque hay más manifestaciones obreras. De alguna manera, la gente se anima más a salir a la calle.

Y ahí es donde el fotoperiodismo va acompañando este proceso y le va dando visibilidad en los espacios públicos.

Claro, hay una cosa que empieza a ser visible. Mi foto de las Madres, cuando la caballería las atropella, es del 82 . O sea, ahí ya hay represión en la calle. Antes lo que hay es lo que nunca pudimos fotografiar: un secuestro, un centro clandestino de detención, ese tipo de cosas. Lo que yo decía antes: nuestro

Picadero y una semana después fue mandado quemar por el propio régimen militar, pero sobrevivió y se fortaleció por el apoyo de la población y algunos sectores del medio intelectual, con personajes como Ernesto Sábato, Jorge Luis Borges y Adolfo Pérez Esquivel.

\section{()ㅜ(1) 3}


trabajo fue más un trabajo de símbolo que de hecho puntual. Yo siento que tengo más hechos puntuales fotografiados en la democracia, como la última foto del guerrillero de La Tablada que se rinde y después lo fusilan o lo hacen desaparecer, que de la época de la dictadura, porque eso no se veía. ${ }^{21}$

Claro.

Y la del 83 es una muestra que tiene un condimento político extra, que es que cuando la vamos a inaugurar, todavía en dictadura, pero ya con el gobierno de Alfonsín electo [Alfonsín ganó las elecciones el 30 de octubre del 83, y asumió el poder el 10 de diciembre]. En ese lapso, nosotros inaugurábamos la muestra. En ese intermedio, el Ministerio del Interior nos prohíbe la muestra, no nos da el edificio, y lo que pasa en ese momento es un hecho que hace tan convocante a la muestra, y que fue que Alfonsín, ya electo, se instaló en un hotel, en el centro de Buenos Aires, que se llama Panamericano, donde empezó a conformar su gabinete, a entrevistarse con otros partidos políticos, con el peronismo, y demás. Y nosotros estábamos todo el tiempo ahí, porque ahí entraban las personalidades políticas que podían hacerse cargo del nuevo gobierno. Como nos prohíben eso, nosotros vamos y le contamos esto a Tróccoli, que era un dirigente radical muy importante, que se iba a transformar en el ministro del Interior. En ese momento, ese Ministerio era como es hoy el jefe de Gabinete, o sea, el primer ministro. Y él nos promete, después de una entrevista con Alfonsín, que el día después de asumir nos van a dar el lugar para hacer la muestra. Entonces nosotros hacemos una conferencia de prensa ahí, donde estábamos nosotros mismos. O sea, nos autoconvocamos como grupo de reporteros gráficos y damos una conferencia de prensa diciendo que la dictadura nos prohibió la muestra y que el presidente se comprometió en darnos el lugar. Todo esto generó colas de gente en la calle para ir a ver la inauguración de la muestra. Qué sé yo la fantasía que tenía la gente que iba a encontrar ahí, pero bueno, ahí se encuentran más fotos de Madres de Plaza de Mayo, más fotos de represión, ahí yo pongo por primera vez mi foto de los militares

${ }^{21}$ El asalto a La Tablada se refiere al intento de toma de un regimiento de infantería ubicado en el cuartel militar de La Tablada por parte de un comando guerrillero denominado Movimiento Todos por la Patria (MTP) el 23 y 24 de enero de 1989, comandado por Enrique Gorriarán Merlo, ex jefe del grupo guerrillero del Ejército Revolucionario del Pueblo (ERP). El saldo final fue dos policías, nueve militares y 32 guerrilleros muertos. En esas trágicas jornadas, Longoni tomó desde una terraza las fotografías con vida de Iván Ruiz y José Alejandro Díaz, cuyos cuerpos nunca aparecieron. La Suprema Corte de Justicia reabrió el caso en 2015 por considerarlo un crimen de lesa humanidad y pidió las imágenes del fotógrafo como prueba pericial.

\section{()(1) $(3$}


que en ese momento se llamaba Vista al frente (yo le había puesto ese título) y mi foto de Videla que se llamaba Treinta mil, por los desaparecidos. Ese es el primer momento en que dos de mis fotos más emblemáticas ven la luz.

Estas fotos no habían circulado antes.

No. Digo esto desde el punto de vista individual. Después hay un montón de fotos de otros colegas que en ese momento empiezan a circular. Y esa es la muestra en que nosotros decimos: "Bueno, ¿y ahora qué?" Al principio nosotros conformamos una lista para intentar ganar la comisión directiva de la Asociación de Reporteros Gráficos, para tener más respaldo, pero perdimos. En nuestro primer intento perdimos y seguimos con la muestra. Yo no recuerdo cuándo la muestra pasa a ser de la asociación. Pero pasa a ser de ella cuando nosotros ganamos las elecciones. En un momento las ganamos. En el primer intento las perdimos, eso me acuerdo bien. Nosotros pensábamos que iba a ser un paseo ganarla, porque éramos más, pero bueno, los otros eran más pícaros. Y sacaron del padrón no sé cuánta cantidad de gente que empezó a votar, que tenía la credencial, pero nosotros no la conocíamos y nos ganaron por, no sé, diez votos, una cosa así, pero nos ganaron.

Esto ocurrió en el contexto de esa tercera exposición.

Sí, en ese momento. No me acuerdo si las elecciones son a fines del 83, en el 84 , pero el primer intento me acuerdo que nosotros hicimos una campaña seria, de cuáles eran nuestros fundamentos. Yo me acuerdo que yo era muy chico entonces, iba como vocal o no sé qué cosa, pero perdimos.

\section{¿Y ustedes convocan a la tercera exposición?}

Sí. La tercera la convocamos nosotros. La cuarta ya no me acuerdo exactamente dónde se hace. Y además hay un momento en que cuando la toma la asociación era imposible de editar esa muestra. Porque hasta ese momento cada socio podía mandar hasta tres fotografías, y todas las fotos que se mandaban, se colgaban. En un momento era tal el desborde que cuando ya la asociación es nuestra (en el sentido en que nosotros ganamos las elecciones), a alguien se le ocurre hacer un comité de selección, y muchos de nosotros (pero sobre todo liderados por mí, porque yo era muy fundamentalista en esa época), dijimos que no, que el sentido de la muestra era que cada socio pusiera lo que quisiera y no sé, que hiciéramos un kilómetro de pared si fuese necesario, pero que ese era el sentido de la muestra y si no, ya era otra muestra distinta. Pero bueno, perdemos en esa discusión. Yo hoy lo miro desde la perspecti-

\section{(ㅇ)(1) $(3$}


va de los años y me parece que la propuesta del comité era razonable. Pero bueno, yo en ese momento era un joven idealista y no solamente me enojé, sino que durante un par de años no mandé fotos a la muestra que yo había fundado. Pero hoy, viendo las muestras que hay, con un comité, que es muy exhaustivo, las muestras son una delicia desde el punto de vista fotográfico, tienen una coherencia, y eso es lógico. Bueno, me parece que hoy lo entiendo. También me entiendo yo en ese momento, era la bandera fundamental esa historia de que en la muestra entra lo que cada uno quiere publicar porque no nos dejan los medios publicarlo. Yo siempre fui muy pasional, con mi ideología, con mis amores, y por supuesto con la fotografía también.

\section{Una mirada irónica sobre la Iglesia católica}

En la primera exposición, tu mandaste la fotografía titulada Astros.

Sí... de monseñor [Juan Carlos] Aramburu como el jefe de la Iglesia católica en Argentina, un tipo muy comprometido con la dictadura. ${ }^{22}$

¿Y cómo fue que tomaste esa foto? ¿En qué contexto?

Es una procesión de la Iglesia católica, creo que es Corpus Christi. Ellos recorrían distintos lugares y van por la calle Corrientes, donde había varios teatros de revista. El teatro de revista es un genero medio vodevill, entre cómicos, vedetes, plumas, mujeres medio ligeras de ropa y demás, que tuvo mucho éxito de los cincuenta a los setenta. Ellos pasan por ahí, y yo hago la foto. No solamente estaba monseñor Aramburu, sino que estaban todos estos caballeros que los podías ver en general en las procesiones religiosas, en la sociedad rural, acompañando actos en los regimientos y demás, que representaban al establishment económico y político de la derecha argentina, circulando por la calle Corrientes, como enfrente de esta cuestión del teatro de revista, que es como apareció el cabaret, el teatro de baja reputación.

${ }^{22}$ Monseñor Juan Carlos Aramburu es un personaje clave para analizar el vínculo de la alta jerarquía católica con la dictadura. Arzobispo de Buenos Aires en 1975 y cardenal a partir de 1976. Estrecho colaborador y defensor de los militares. En 1982, ante las preguntas de la prensa y otros sectores que le cuestionaban por la existencia de los desaparecidos, Aramburu realizó las siguientes declaraciones que le dieron la vuelta al mundo y lo retratan de cuerpo entero: "En la Argentina no hay fosas comunes y a cada cadáver le corresponde un ataúd. Todo se registró regularmente en los correspondientes libros. ¿Desaparecidos? No hay que confundir. Hay desaparecidos que viven tranquilamente en Europa."

\section{()ㅜ(1) $\$$}




\section{SECUENCIA}

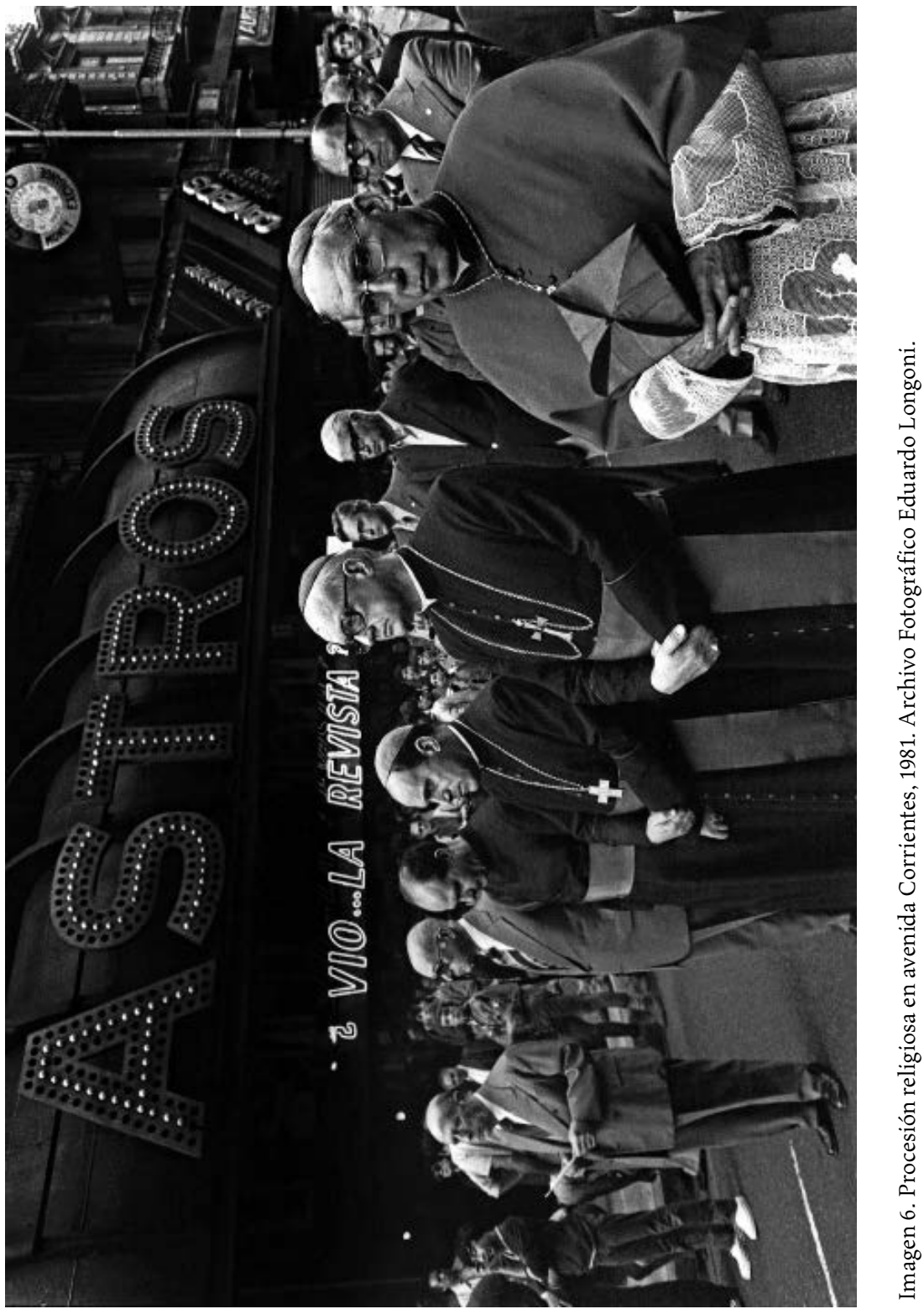

\section{(ㅇ)(1) $\$$}


Es una mirada muy irónica...

La mirada irónica se me empieza a generar tratando de colar alguna opinión en ese momento de censura tan rígida, que nos permitiera decir cosas con una cierta segunda intención. Había una posibilidad de eso, que era por donde se filtraba la imagen, no sé, un gesto ridículo de un dictador, en ese lugar nosotros empezamos a usar la mirada en ese sentido.

Es una foto que muy probablemente no iba a comprar nadie. ¿A qué obedece el móvil de tomar ese tipo de fotos?

Hay muchas fotos en las que yo sabía que cuando apretaba el obturador no la iban a publicar, que la agencia ni siquiera la iba a transmitir, pero eran las fotos que me interesaban a mí y que me interesaba mostrar. Sabía que en cualquier momento podían interesar y además empezaban a formar mi propio álbum.

\section{Las "grietas" de la dictadura}

El fotógrafo mexicano Rodrigo Moya tiene este concepto de la "doble cámara", según el cual él iba con dos cámaras en su mente, una para la empresa para la cual estuviera trabajando en ese momento y la otra, mucho más íntima y personal, para tomar una serie de cosas que él sabía que tenían otra dimensión. Esto parece aplicarse a lo que tú estás diciendo. ${ }^{23}$

Sí. Yo trabajaba en un lugar que nos alentaba mucho a la mirada. Cuarterolo la miraba y se reía, y su imposibilidad de moverla por una cuestión política hacía que tuviera la responsabilidad de no elegirla, pero emitía una opinión sobre eso. O sea, había una cuestión de entender que había una mirada, tal vez la mirada no se podía publicar, pero él te alentaba a construir esa mirada. Eso fue una de las cosas positivas de laborar en un lugar así, que era que no tenía una mirada contraria a eso sino que había un aliento para que hicieras ese tipo de cosas. Tal vez no se podían publicar, pero él te decía: “QQué buena foto!”

Esto nos permite llegar a este concepto de la censura y la autocensura. A veces la autocensura es más importante, sobre todo en medios donde se sabe que lo que no se

${ }^{23}$ Rodrigo Moya es uno de los fotógrafos documentalistas más importantes de México en la segunda mitad del siglo xx y autor de una de las reflexiones más agudas sobre el ejercicio del fotoperiodismo en México. Tuve la oportunidad de mostrar a Longoni algunos libros sobre la obra de Moya para propiciar este diálogo.

\section{()ㅜ(1) $\$$}


va a publicar no tiene ni siquiera caso imaginar, pero aquí es todo lo contrario, por lo que tú me dices, se sabe que la foto no se va a vender en ese momento, pero sí existe el espacio para pensar en ese tipo de imagen y además se valora ese tipo de mirada. La agencia podía autocensurarse, no dar una foto, pero te alentaba a hacerla y nosotros teníamos esa mirada del no dejar de hacerlo, o sea, no nos autocensurábamos nosotros mismos como fotógrafos, o yo por lo menos no lo hacía, y siempre sentí el aliento con eso.

Nunca sentí que me dijeran: "Escuchame, por qué haces esta foto que no se puede publicar." Al contrario, había un aliento para decir: "¡Qué buena foto, pero no la podemos dar!" Cuarterolo me ayudó a encontrarle el tono y el encuadre a la foto de los militares, porque primero la foto yo la había copiado vertical, como tenía una velo, y él me dijo: "Copiala hasta acá". De ninguna manera la transmitimos, pero él me ayudo, él vió la foto. Creo que después de la foto de la "Mano de Dios" de Maradona contra los ingleses, esta ha sido mi foto más publicada, y sin embargo en ese momento no se publicó, pero así lo hacíamos todo el tiempo. ${ }^{24}$

También había una cosa lúdica con la cámara, nosotros fotografiábamos, nos gustaba la fotografía, entonces no pensábamos mucho en lo que se iba a publicar o no, pensábamos en nuestras fotos...

¿Y la parte de la censura de la dictadura se daba en la agencia?

Sí.

\section{¿Cómo operaba?}

En esos momentos yo no era editor, no estaba muy interiorizado de dónde estaba el límite, cómo se cruzaba o cómo no se cruzaba, y confiaba en la palabra de los editores. A mí me importaba más el hecho de aprender, que la cuestión de si se publicaba o no, entre otras cosas porque tu nombre tal vez no salía nunca. Lo más que salía en la foto era: "Fotografía NA, Eduardo Longoni”, pero nadie lo publicaba así, nosotros éramos trabajadores anónimos. ¿Cuál era como el decálogo de lo que se podía publicar o no? Los primeros

24 "La mano de Dios" es el nombre con el que se conoce al primer gol realizado con la mano por Diego Armando Maradona y convalidado oficialmente por el árbitro de Túnez Ali Bennaceur en el partido de futbol de cuartos de final del mundial de México 86, en el que los argentinos vencieron a los ingleses por dos goles a uno. En los vestidores el astro argentino declaró que el gol lo había marcado "un poco con la cabeza y un poco con la ayuda de la mano de Dios", y fue bautizado de inmediato por los medios de esa manera. Existen varias versiones fotoperiodísticas del famoso gol. Una de las más conocidas es la registrada por Longoni.

\section{()(1) $\$$}


años de cuando yo era solamente fotógrafo no lo recuerdo muy bien. De todas maneras las agencias son más jugadas que los medios, porque vos en una agencia puedes publicar una foto difícil de digerir, como una guerra, después el que va a decidir si la publica o no va a ser el medio. Vos la mandás, pero el medio tiene que hacer la selección.

La agencia me parece que en ese sentido debe haber transmitido unas cien fotos de las Madres y sólo se publicaban cinco, pero nosotros igual las hacíamos y nos quedábamos con la conciencia tranquila de que las mandábamos. Yo empecé a ser editor de la agencia cuando ya estábamos en democracia. Empecé a ser editor en el 84, o sea, ahí es donde me empiezo a interiorizar más qué cosas voy a mandar y qué cosas no.

En la exposición de 1981 se enfrentan a ese horizonte de la posible censura o por lo menos imaginan cuáles pueden ser percibidas como políticamente incorrectas.

La idea de la muestra fue que no había comité de selección, sólo había un comité organizador y cada uno mandaba lo que quería. No nos encontramos con un problema de decir: "Nos da miedo esta foto o nos deja tranquilos la otra." En todo caso, creo que uno tiene siempre un poco de miedo en cualquier situación donde se expone a una situación de violencia fotografiando. No tuvimos problema con determinada foto, me parece que lo que nos generaba cierta inquietud era ver si no nos levantaban la muestra entera, si no nos incendiaban el local o lo que fuera. No es que hubo alguna foto que nos condicionó, de hecho hay fotos de las Madres. Mi foto era de la jerarquía de la Iglesia católica y de la dictadura. Tomar una foto irónica de la Iglesia podía ser comprometido, y sin embargo teníamos la sensación de protegernos entre todos, así que no tuvimos demasiado miedo. Teníamos un Falcon verde de los que usaban las "patotas" en la puerta en la inauguración, pero no hubo ningún incidente. No solamente no lo hubo, sino que los medios más grandes hicieron prensa de eso, o sea, la noticia de la muestra salió publicada en los diarios, lo cual de alguna manera me parece que también nos dio una cobertura en algún momento. ${ }^{25}$

Yo también pienso que uno se mete por las grietas de los regímenes. En el año 81 ya había grietas. "Teatro Abierto" fue una. Más allá de que la dictadura era fuerte, todavía no había llegado la guerra de las Malvinas. Cuando la

${ }^{25}$ Con el término de "patota" se designa al grupo de represores militares y civiles encargados de secuestrar a las personas y llevarlas a los centros de cautiverio y exterminio en los años de la dictadura. Por lo general operaban en autos marca Falcon, los cuales se convirtieron con los años en un símbolo del régimen asociado al tema de las desapariciones (Fortuny, 2014, pp. 62-63).

\section{()(1) $(3$}


dictadura pierde las Malvinas empieza a batirse en retirada, pero, por ejemplo, la dictadura censura la tercer muestra del 83 y no nos deja hacerla porque eso era en la sede de un edificio de la oEA que dependía del Ministerio del Interior, y sin embargo no censura las muestras anteriores. O sea, la dictadura en retirada nos censura la muestra del 83, pero no censura la de los dos años anteriores. Son ese tipo de cosas que yo llamo "grietas". Te metes por un lugar y bueno...

\section{Las transformaciones de la militancia}

Me gustaría concluir retomando esto que has señalado de que poco a poco vas adquiriendo la perspectiva del fotógrafo, que es distinta del manifestante. Son dos lugares distintos. Entraste a trabajar en la agencia siendo todavía militante y esta perspectiva es distinta de la del profesional que tiene cierta distancia para cubrir las cosas. Entonces, ¿qué pasó con tu militancia?, ¿cómo se transformó en estos primeros años de trabajo profesional?

Dejé de militar apenas salí de la colimba [servicio militar], o mejor dicho, pedí una licencia a mi militancia al entrar a la colimba como hacíamos todos, porque estábamos en una situación complicada, y nunca volví a militar. Para mí la militancia se transformó en mi lucha con la cámara, o sea, yo me desvinculé del PC en el 78, y no volví a militar nunca más. Es más, después estuve en desacuerdo con la política del partido, que terminó teniendo como cierta mirada permisiva con un ala de la dictadura. Nunca volví a militar en política activamente, y mi militancia fue con la cámara, con tratar de contar lo que pasaba en la época de la dictadura. Tuve una agencia durante los siguientes tres años, pero no volví a militar en política.

Vamos a cerrar aquí esta entrevista que pone fin a un primer ciclo dentro de tu trayectoria profesional. Muchas gracias.

\section{LISTA DE REFERENCIAS}

Feld, C. (2012). Fotografía y desaparición en Argentina. Consideraciones sobre la foto de Alice Domon y Léonie Duquet tomada en el sótano de la ESMA. En A. Triquell y C. Feld, Artículos de investigación sobre fotografía (pp. 37-82). Montevideo: CMDF.

Fortuny, N. (2014). Memorias fotográficas. Imagen y dictadura en la fotografía argentina contemporánea. Buenos Aires: La Luminosa.

\section{(ㅇ)(1) $(9$}


Gamarnik, C. (2009). Reconstrucción de la primera muestra del periodismo gráfico durante la dictadura argentina. En V Jornadas de jóvenes investigadores, Instituto de Investigaciones Gino Germani, Facultad de Ciencias Sociales, Universidad de Buenos Aires, pp. 123-145.

Gamarnik, C. (2010). La construcción de la imagen de las Madres de Plaza de Mayo a través de la fotografía de prensa. Afuera. Estudios de Crítica Cultural y Artes Visuales, 9.

Gamarnik, C. (2011). Imágenes de la dictadura militar. La fotografía de prensa antes, durante y después del golpe de Estado de 1976 en Argentina. En S. Pérez y C. Gamarnik (eds.), Artículos de investigación sobre fotografía. Montevideo: CMDF.

Jelin, E. (2012). Los trabajos de la memoria. Lima: Instituto de Estudios Peruanos.

Longoni, E. (2012). Violencias. Buenos Aires: Libros del Náufrago.

Lvovich, D. y Bisquert, J. (2008). La cambiante memoria de la dictadura. Discursos públicos, movimientos sociales y legitimidad democrática. Buenos Aires: Universidad Nacional de General Sarmiento.

Thomson A. y Freund A. (2011). Oral history and photography. Nueva York: Palgrave Macmillan.

\section{OTRAS FUENTES}

\section{Bibliografía}

Gorini, U. (2006). La rebelión de las Madres. Historia de las Madres de la Plaza de Mayo (2 vols.). Buenos Aires: Ed. Norma.

Longoni, A. y Bruzzone G. (comps.), (2008). El siluetazo. Buenos Aires: Adriana Hidalgo editora.

Longoni, E. y Cuarterolo, M. A. (1996). El poder de la imagen. Apuntes sobre fotografía periodística. Buenos Aires: Documenta.

Menajovsky, J. y Brook G. (2006). Nuevas tecnologías y viejas certidumbres. Masacre de Avellaneda en la fotografía periodística. En S. Boggi y G. Brook (comps.). Discursos para oír y para ver (pp. 73-108) Buenos Aires: Nueva Generación.

Novaro, Marcos y Palermo, V. (2003). La dictadura militar (1976-1983): del golpe de Estado a la restauración democrática. Buenos Aires: Paidós.

Ricoeur, P. (2000). La mémoire, l'histoire, l'oubli. París: Le Seuil.

\section{(ㅇ)(1) $\$$}

